\title{
Cathepsin S Activity Regulates Antigen Presentation and Immunity
}

\author{
Richard J. Riese, ${ }^{\star}$ Richard N. Mitchell, ${ }^{\circ}$ Jose A. Villadangos, ${ }^{\S}$ Guo-Ping Shi, ${ }^{\star}$ James T. Palmer, Elena R. Karp, ${ }^{\star}$ \\ George T. De Sanctis, ${ }^{\star}$ Hidde L. Ploegh, ${ }^{\S}$ and Harold A. Chapman` \\ *Department of Medicine, Brigham and Women’s Hospital and Harvard Medical School, Boston, Massachusetts 02115; ${ }^{*} I m m u n o l o g y$ \\ Research Division, Department of Pathology, Brigham and Women's Hospital and Harvard Medical School, Boston, Massachusetts \\ 02115; ${ }^{\S}$ Department of Pathology, Harvard Medical School, Boston, Massachusetts 02115; and $\|_{\text {Arris Pharmaceuticals, South San }}$ \\ Francisco, California 94080
}

\begin{abstract}
MHC class II molecules display antigenic peptides on cell surfaces for recognition by $\mathrm{CD}^{+} \mathrm{T}$ cells. Proteolysis is required in this process both for degradation of invariant chain (Ii) from class II-Ii complexes to allow subsequent binding of peptides, and for generation of the antigenic peptides. The cysteine endoprotease, cathepsin S, mediates Ii degradation in human and mouse antigen-presenting cells. Studies described here examine the functional significance of cathepsin $S$ inhibition on antigen presentation and immunity. Specific inhibition of cathepsin S in A20 cells markedly impaired presentation of an ovalbumin epitope by interfering with class II-peptide binding, not by obstructing generation of the antigen. Administration of a cathepsin $S$ inhibitor to mice in vivo selectively inhibited activity of cathepsin $S$ in splenocytes, resulting in accumulation of a class II-associated Ii breakdown product, attenuation of class II-peptide complex formation, and inhibition of antigen presentation. Mice treated with inhibitor had an attenuated antibody response when immunized with ovalbumin but not the T cell-independent antigen TNP-Ficoll. In a mouse model of pulmonary hypersensitivity, treatment with the inhibitor also abrogated a rise in IgE titers and profoundly blocked eosinophilic infiltration in the lung. Thus, inhibition of cathepsin $\mathrm{S}$ in vivo alters Ii processing, antigen presentation, and immunity. These data identify selective inhibition of cysteine proteases as a potential therapeutic strategy for asthma and autoimmune disease processes. ( $J$. Clin. Invest. 1998. 101:2351-2363.) Key words: histocompatibility $\bullet$ class II $\bullet$ proteinase $\bullet$ inhibitor $\bullet$ ovalbumin
\end{abstract}

\section{Introduction}

MHC class II molecules bind and display antigenic peptides as class II-peptide complexes on the cell surface of antigen-presenting cells (APCs) ${ }^{1}$ for recognition by $\mathrm{CD}^{+} \mathrm{T}$ helper cells (1-3). The molecular mechanisms leading to formation of class II-peptide complexes and presentation of antigen on the cell

Address correspondence to Harold A. Chapman, M.D., Department of Medicine, Brigham and Women's Hospital, 75 Francis Street, Boston, MA 02115. Phone: 617-732-6074; FAX: 617-232-4623.

Received for publication 10 July 1997 and accepted in revised form 12 March 1998.

J. Clin. Invest.

(C) The American Society for Clinical Investigation, Inc. 0021-9738/98/06/2351/13 \$2.00

Volume 101, Number 11, June 1998, 2351-2363

http://www.jci.org surface begin with synthesis of class II $\alpha \beta$ heterodimers in the endoplasmic reticulum. Early during biosynthesis these $\alpha \beta$ heterodimers associate with a type II membrane protein, the invariant chain (Ii), to form a nonameric complex of $\alpha \beta \operatorname{Ii~(4,~}$ 5). Ii associates with class II molecules via direct interaction of residues 81-104 of its lumenal domain $(6,7)$, designated CLIP (class II-associated Ii peptide), with the antigen binding groove of class II (8-10). This $\alpha \beta$ Ii complex traverses the Golgi apparatus and is delivered to intracellular compartments (11-13). In these acidic compartments, the Ii is degraded and liberated from the $\alpha \beta$ Ii complexes, allowing class II molecules to encounter and bind antigenic peptides. Most class II alleles require an additional class II-like molecule, HLA-DM (murine $\mathrm{H}-2 \mathrm{M}$ ), to liberate the peptide-binding groove of CLIP, and to facilitate loading with antigenic peptide (14-16).

Proteolysis participates in generation of class II-peptide complexes at two critical junctures. First, proteolytic degradation of the Ii is a prerequisite for peptide binding to class II molecules, as intact $\alpha \beta$ Ii trimers themselves are unable to bind peptides (17). Inhibition of Ii degradation in B lymphoblastoid cells and murine spleen cells leads to accumulation of class IIassociated Ii fragments and inhibition of class II-peptide formation (18-21). Second, proteolysis of large polypeptides is required to generate the antigen presented by class II molecules (3). These peptide antigens are 15-25 amino acids long, and are generated in the endosomal pathway from both exogenous and endogenous sources (8). Selective inhibition of the proteases responsible for both these degradative processes is a potential mechanism for modulating the immune response.

Several lysosomal proteases have been implicated in the processing of Ii and antigenic peptides. Cathepsin B, the most abundant cysteine protease, has been tied to Ii degradation using purified class II-Ii complexes (22). Cathepsin L, a potent cysteine-class endoprotease, binds to and is specifically inhibited by a fragment of the alternatively spliced Ii form p41 (23). Overexpression of p41 in class II- and Ii-transfected mouse fibroblasts results in inhibition of cathepsin L activity and accumulation of Ii degradation products (24). Interestingly, this leads to enhanced presentation of some antigenic peptides, suggesting that cathepsin $\mathrm{L}$ may be involved in Ii processing as well as peptide degradation in these cells. Cathepsin D, a prominent aspartyl protease, is able to generate antigenic peptides capable of associating with class II molecules $(25,26)$.

We have shown recently that another cysteine protease, cathepsin S, plays a key role in processing Ii in human B lymphocytes (27). Cathepsin S possesses potent endoproteolytic

1. Abbreviations used in this paper: APCs, antigen-presenting cells; BAL, bronchoalveolar lavage; CLIP, class II-associated Ii peptide; HRP, horseradish peroxidase; Ii, invariant chain; OVA, ovalbumin; PC, phosphorylcholine; TNP, trinitrophenol. 
activity, is highly expressed in APCs, has a broad pH activity profile, and is upregulated by IFN- $\gamma$. Specific inhibition of cathepsin $\mathrm{S}$ in human B lymphoblasts causes accumulation of a 13-kD Ii breakdown intermediate, interfering with subsequent class II-peptide association. Purified human cathepsin S, but not cathepsins B or D, is able to completely degrade Ii from class II-Ii complexes, generating class II-CLIP. In mouse splenocytes, inhibition of cathepsin $\mathrm{S}$ also induces buildup of Ii breakdown products and attenuation of class II-peptide association, although the extent of this effect appears to be haplotype dependent (28). Studies presented here expand upon the biochemical alterations in Ii processing and class II-peptide binding to examine the functional effects of cathepsin $\mathrm{S}$ inhibition in murine B lymphocytes and in vivo immunity. First we show that specific inhibition of cathepsin $S$ with the vinyl-sulfone inhibitor LHVS (29) in a mouse B cell line blocks presentation of an immunodominant ovalbumin (OVA) peptide (30) by interfering with class II-peptide association, not by inhibiting generation of this antigenic peptide. Next, we document that in vivo administration of LHVS selectively inhibits cathep$\sin \mathrm{S}$ and interferes with Ii processing and antigen presentation in murine spleen cells. This, in turn, leads to a diminished immune response to OVA as characterized by antibody titers and lung eosinophilia in a murine model of pulmonary hypersensitivity. These findings suggest that cathepsin S plays an important role in processing of class II-Ii in mouse B cells to generate class II molecules competent for binding antigenic peptide, and that inhibition of cathepsin $\mathrm{S}$ is possible in vivo and has important functional consequences in modulating the immune response.

\section{Methods}

Materials. Cbz-Tyr-Ala- $\mathrm{CN}_{2}$ was a generous gift from Dr. Elliot Shaw (Friedrich Miescher-Institut, Basel, Switzerland). LHVS (morpholinurea-leucine-homophenylalanine-vinylsulfone phenyl), an irreversible, specific cathepsin $\mathrm{S}$ inhibitor was prepared as described previously (Arris Pharmaceuticals, South San Francisco, CA) (29). Stock solutions of LHVS were made in DMSO. OVA was purchased from Sigma Chemical Co. (St. Louis, MO) and was phosphorylcholine (PC)-haptenated as described previously (31).

$\left[{ }^{35} \mathrm{~S}\right]$ Methionine/cysteine, $\left[{ }^{3} \mathrm{H}\right]$ thymidine, and ${ }^{125} \mathrm{I}$ were obtained from DuPont New England Nuclear (Boston, MA). Protein A-agarose was purchased from Boehringer Mannheim (Indianapolis, IN). Methionine-, cysteine-free DME, penicillin/streptomycin $(100 \times)$, Hepes $(100 \times)$, nonessential amino acids $(100 \times)$, sodium pyruvate $(100 \times)$, and glutamine $(100 \times)$ were obtained from GIBCO BRL (Gaithersburg, MD). RPMI was purchased from Fisher Scientific (Pittsburgh, PA) and FBS was obtained from Hyclone Labs (Logan, UT). Normal rabbit serum, normal mouse serum, 2-mercaptoethanol, Ficoll, Histopaque, $o$-phenylenediamine dihydrochloride, Percoll, Tween 20, avidin-peroxidase, and BSA were purchased from Sigma. Maxisorb Nunc immunoplates were purchased from Marsh, Inc. (Rochester, NY). The trinitrophenol (TNP)-Ficoll and TNP-BSA were purchased from Solid Phase Sciences (San Rafael, CA).

Antibodies. N22 is a hamster $\mathrm{mAb}$ that recognizes mouse MHC class II molecules (32), and was a gift of Dr. R.M. Steinman (The Rockefeller University, New York). The anti-mouse IgE antibody, anti-mouse kappa light chain conjugated to biotin, and anti-mouse IgM conjugated to horseradish peroxidase (HRP) were purchased from PharMingen (San Diego, CA). The secondary HRP antibody used in the OVA-specific IgG + IgM titers was purchased from Kirkegaard \& Perry (Gaithersburg, MD). Antiserum against mouse cathepsin L was a gift of Dr. M.M. Gottesman (National Institutes of Health, Bethesda, MD) and anti-human cathepsin B, which crossreacts with mouse cathepsin B, was purchased from Athens Research (Athens, GA). Antiserum against mouse cathepsin S was raised using methods as described previously (33).

Animals. Female C57BL/6 mice (6-8 wk old) were purchased from Harlan Sprague Dawley (Indianapolis, IN) and The Jackson Laboratories (Bar Harbor, ME). Animals were housed in a viral-free barrier facility.

Cell culture. The mouse B cell hybridoma line A20 $\left(\gamma 2 \mathrm{a}^{+}, \mathrm{\kappa}^{+}\right.$, $\mathrm{H}-2^{\mathrm{d}}$ ), transfected with PC-specific human $\mu$ heavy chain (31) was maintained in RPMI with $10 \%$ FBS, 1:1,000 U/ml penicillin, $100 \mathrm{mg} /$ $\mathrm{ml}$ streptomycin, and $2 \mathrm{mM}$ glutamine. The $\mathrm{T}$ cell hybridoma cell line DO.11.10 recognizes OVA peptide 323-339 ( OVA $\left._{323-339}\right)$ in context of $\mathrm{I}-\mathrm{A}^{\mathrm{d}}$ and $\mathrm{I}-\mathrm{A}^{\mathrm{b}}(30,34)$ and was maintained in RPMI supplemented with FBS, glutamine, penicillin/streptomycin as above in addition to $50 \mu \mathrm{M}$ 2-mercaptoethanol, $10 \mu \mathrm{M}$ nonessential amino acids, and $100 \mu \mathrm{M}$ sodium pyruvate. The IL-2-dependent cell line HT-2 was maintained in the same medium supplemented with $100 \mathrm{U} / \mathrm{ml} \mathrm{IL}-2$. The I-A ${ }^{\mathrm{d}}-$ expressing M12.4.1 cell line and its class $\mathrm{II}^{-}$variant M12.C.3 (35) were generous gifts of Dr. Laurie Glimcher (Harvard School of Public Health, Boston, MA), and were maintained in the same medium.

Active site labeling of cysteine proteases. The cysteine protease inhibitor Cbz-Tyr-Ala- $\mathrm{CN}_{2}$ was iodinated as reported previously (36). A20 cells (4 million/sample) in RPMI were incubated with LHVS or DMSO vehicle at $37^{\circ} \mathrm{C}$ for $1 \mathrm{~h}$ before labeling. Cells were then labeled by incubation with Cbz-[125 I]-Tyr-Ala- $\mathrm{CN}_{2}$ for $1 \mathrm{~h}$ at $37^{\circ} \mathrm{C}$, washed twice with PBS, and lysed in SDS-PAGE sample buffer. Mouse spleen cells (10 million/sample) were labeled as above without prior incubation with inhibitors.

Metabolic labeling and class II immunoprecipitation. Mouse spleen cells (20 million/sample) were preincubated in $1 \mathrm{ml}$ methionine-, cysteine-free DME for $1 \mathrm{~h}$ at $37^{\circ} \mathrm{C}$ before labeling with $0.55 \mathrm{mCi}\left[{ }^{35} \mathrm{~S}\right] \mathrm{me}-$ thionine/cysteine for $1 \mathrm{~h}$ at $37^{\circ} \mathrm{C}$. The cells were centrifuged and resuspended in RPMI $10 \%$ FBS and chased for $4 \mathrm{~h}$. Then, the cells were washed twice with cold PBS and lysed in $1 \mathrm{ml}$ of $50 \mathrm{mM}$ Tris$\mathrm{HCl}, \mathrm{pH} 7.4,0.5 \% \mathrm{NP}-40,5 \mathrm{mM} \mathrm{MgCl}_{2}$. Lysates were precleared with protein A-agarose, $7 \mu \mathrm{l}$ of normal rabbit serum, and $2 \mu \mathrm{l}$ of normal mouse serum followed by immunoprecipitation with mAb N22 coupled to protein A-agarose. Immunoprecipitates were washed four to six times with $1 \mathrm{ml}$ of $50 \mathrm{mM}$ Tris- $\mathrm{HCl}, \mathrm{pH} 7.4,0.5 \%$ NP-40, $5 \mathrm{mM}$ EDTA, $150 \mathrm{mM} \mathrm{NaCl}$. These pellets were eluted directly with nonreducing or reducing SDS-PAGE sample buffer and analyzed by $12 \%$ SDS-PAGE.

Subcellular fractionation. A20 cells were fractionated as previously described (37). Briefly, cells were suspended in $6 \mathrm{ml}$ homogenization buffer $(0.3 \mathrm{M}$ sucrose, $0.01 \mathrm{M}$ Hepes, $10 \mu \mathrm{g} / \mathrm{ml}$ leupeptin, 40 $\mu \mathrm{g} / \mathrm{ml}$ pepstatin A, and $200 \mu \mathrm{M}$ PMSF, $\mathrm{pH}$ 7.2) and ruptured by nitrogen cavitation after an equilibrium at $450 \mathrm{psi}$ for $5 \mathrm{~min}$ at $4^{\circ} \mathrm{C}$. Postnuclear supernatants were centrifuged over $24 \mathrm{ml}$ of $25.4 \%$ Percoll with $0.3 \mathrm{M}$ sucrose, $0.01 \mathrm{M}$ Hepes, and the same protease inhibitors as above $(\mathrm{pH} 7.2, \delta=1.129 \mathrm{~g} / \mathrm{ml})$ for $65 \mathrm{~min}$ at $30,000 \mathrm{~g}$. Fractions of $0.8 \mathrm{ml}$ were recovered from each gradient by gravity siphon.

The distribution of plasma membrane was defined by enzymatic activity of alkaline phosphodiesterase I, and the distribution of lysosomes was determined by activity of $\beta$-hexosaminidase as previously described (37). The distributions of human $\mathrm{mIgM}$ and murine class II molecules were detected by ELISA as previously described (37).

Antigen presentation assays. A20 cells were incubated with $2 \mathrm{nM}$ LHVS or vehicle for $1 \mathrm{~h}$ at $37^{\circ} \mathrm{C}$. Cells were aliquoted into wells of a 96-well plate at $2 \times 10^{5}$ cells/well in the presence of inhibitor and $0-100 \mu \mathrm{g} / \mathrm{ml}$ final concentration PC-OVA and incubated for $24 \mathrm{~h}$ with $10^{5}$ cells/well of the $\mathrm{T}$ cell hybridoma DO.11. Each sample was assayed in triplicate. Generation of IL-2 was assayed by proliferation of IL-2-dependent cell line HT-2 measured by incorporation of $\left[{ }^{3} \mathrm{H}\right]$ thymidine (38). An IL-2 standard curve was prepared for each experiment. For some control experiments, A20 cells were incubated with LHVS for $1 \mathrm{~h}$ at $37^{\circ} \mathrm{C}$ and then fixed in $1 \%$ paraformaldehyde/PBS for $30 \mathrm{~min}$ at room temperature. The cells were washed four times 
and then incubated $\left(10^{5}\right.$ cells/well $)$ with $2 \mathrm{nM}$ LHVS, $0-50 \mu \mathrm{g} / \mathrm{ml}$ OVA $_{323-339}$ (purchased from Analytical Biotechnology Services, Boston, MA), and DO.11 $\mathrm{T}$ cells for $24 \mathrm{~h}$ at $37^{\circ} \mathrm{C}$.

The distribution of antigenic activity in the Percoll gradients capable of stimulating DO.11 cells was assayed as described previously (37). Briefly, aliquots of each fraction were sonicated (model 250; Branson Ultrasonics Corp., Danbury, CT) with a microtip at power level 1.5 , and incubated for $4 \mathrm{~h}$ at $37^{\circ} \mathrm{C}$ with $5 \times 10^{5}$ paraformaldehyde-fixed class II-positive M12.4.1 or class II-negative M12.C.3 APCs. After washing with culture medium, $10^{5}$ APCs were incubated with $10^{5}$ DO. 11 cells in triplicate in a final volume of $0.2 \mathrm{ml}$. Proliferation of the IL-2 responsive reporter cell HT-2 was assessed after $24 \mathrm{~h}$ as described above. In this assay A20 cell fractions after incubation with PC-F $\left(a b^{\prime}\right) 2-R G G$ are unable to stimulate DO.11 T cells (37). Controls included incubating fixed APC with Percoll plus culture medium, OVA or PC-OVA at $2-4 \mathrm{mg} / \mathrm{ml}$, and OVA $_{323-339}$ at $25 \mu \mathrm{g} / \mathrm{ml}$. Intact OVA cultured with DO.11 cells resulted in no proliferation over background. Likewise, OVA $_{323-339}$ incubated with M12.C.3 class $\mathrm{II}^{-}$APCs and cultured with DO.11 cells showed no stimulation.

Mixed lymphocyte reaction and PHA stimulation. Spleen cells from mice injected with either $100 \mathrm{mg} / \mathrm{kg}$ LHVS or vehicle alone (DMSO) every $48 \mathrm{~h}$ for $14 \mathrm{~d}$ were harvested and aliquoted into microtiter plates at $2 \times 10^{5}$ cells/well. Spleen cells from Balb/c mice were harvested, irradiated (2,000 rads), and aliquoted into the same wells at $2 \times 10^{5}$ cells/well. Each sample was performed in triplicate. Samples were allowed to incubate for $6 \mathrm{~d}$. PHA stimulation was performed by incubating $2 \times 10^{5}$ spleen cells with $10 \mu \mathrm{g} / \mathrm{ml}$ PHA for $3 \mathrm{~d}$. Proliferation was assessed by $\left[{ }^{3} \mathrm{H}\right]$ thymidine uptake $(1 \mu \mathrm{Ci} /$ well $)$ for the final $18 \mathrm{~h}$ of the incubation.

Animal immunization protocols. Mice were injected intraperitoneally with $100 \mathrm{mg} / \mathrm{kg}$ LHVS in DMSO every $48 \mathrm{~h}$ starting $2 \mathrm{~d}$ before immunization and continuing throughout the protocols. Control animals were injected with DMSO alone.

For the first immunization protocol, mice were immunized intraperitoneally on day 0 with $100 \mu \mathrm{g}$ OVA in $100 \mu \mathrm{l}$ of CFA. $7 \mathrm{~d}$ later the animals were boosted with a $200-\mu l$ intraperitoneal injection containing $10 \mu \mathrm{g}$ of OVA and $1 \mathrm{mg}$ of $\mathrm{Al}(\mathrm{OH})_{3}$. Animals were killed on day 14 with $5 \mathrm{mg}$ sodium pentobarbital given intraperitoneally. Postimmune serum was obtained by cardiac puncture and spleen cells were harvested for cysteine protease labeling and evaluation of class II-Ii processing. As a control experiment mice were challenged with a $\mathrm{T}$ cell-independent antigen, TNP-Ficoll, and TNP-specific IgM was measured after $7 \mathrm{~d}$ as described previously (39). Briefly, mice were injected with $100 \mu \mathrm{g}$ of TNP-conjugated Ficoll intraperitoneally in PBS. Animals were killed after $7 \mathrm{~d}$ and serum was collected by cardiac puncture. Preimmune sera in all experiments were obtained retroorbitally after animals were anesthetized with inhalation of $2-5 \%$ halothane.

Allergic pulmonary inflammation was induced as described previously $(40,41)$. Briefly, animals were immunized on day 0 with $0.5 \mathrm{ml}$ containing $8 \mu \mathrm{g}$ OVA and $1 \mathrm{mg} \mathrm{Al}(\mathrm{OH})_{3}$ gel. The OVA was allowed to conjugate to the $\mathrm{Al}(\mathrm{OH})_{3}$ gel for $1 \mathrm{~h}$ at room temperature before immunization. On day 5 the mice were boosted in an identical manner to the initial immunization. On day 12 the mice were exposed to nebulized $0.5 \%$ OVA in PBS for $1 \mathrm{~h}$ in the morning and $1 \mathrm{~h}$ in the afternoon. Animals were killed on day 15 as above.

ELISA for antibody titers. Total serum IgE was assayed by sandwich ELISA. Maxisorb Nunc immunoplates were coated with $2 \mu \mathrm{g} / \mathrm{ml}$ rat anti-mouse IgE mAb clone R35-72 in $0.1 \mathrm{M} \mathrm{NaHCO}_{3}, \mathrm{pH} 8.2$, at $4^{\circ} \mathrm{C}$ overnight. Plates were washed three times with $\mathrm{PBS} / 0.05 \%$ Tween and blocked for $2 \mathrm{~h}$ with PBS $/ 3 \%$ BSA at room temperature. Plates were washed three times and incubated with serum samples diluted in PBS/1\% BSA (1:20-1:500) and incubated overnight at $4^{\circ} \mathrm{C}$. Plates were washed four times and incubated with $2 \mu \mathrm{g} / \mathrm{ml} \mathrm{rat} \mathrm{anti-}$ mouse kappa light chain antibody conjugated to biotin in PBS $/ 1 \%$ BSA for $1 \mathrm{~h}$ at room temperature. Plates were washed five times and incubated with avidin-peroxidase $(1: 5,000)$ for $1 \mathrm{~h}$ at room temperature. Plates were washed six times, developed with $o$-phenylenedi- amine dihydrochloride, and the absorption measured at $450 \mathrm{~nm}$. Results were quantitated against a standard curve generated with a purified mouse IgE standard (PharMingen) and the increase in $\operatorname{IgE}$ between pre-and postimmune serum was calculated for each mouse. Data were then expressed as a stimulation index comprised of the ratio of increased IgE for each immunized mouse divided by the mean increase in IgE for mice injected with adjuvant only.

To measure OVA-specific IgG + IgM, Nunc immunoplates were coated with $20 \mu \mathrm{g} / \mathrm{ml} \mathrm{OVA}$ in $0.1 \mathrm{M} \mathrm{NaHCO}_{3}$, pH 8.2, at $4^{\circ} \mathrm{C}$ overnight. Plates were washed and incubated with diluted serum samples as above. Plates were then incubated with goat anti-mouse $\mathrm{IgG}+$ IgM antibody conjugated to HRP and developed as above. TNP-specific IgM was measured by coating Nunc immunoplates with $20 \mu \mathrm{g} / \mathrm{ml}$ TNP-BSA as above, incubated with diluted serum samples $(1: 1,000)$, and then probed with anti-mouse IgM conjugated to HRP. For each mouse, postimmune serum dilutions in which OD was proportional to dilution were determined and then the change in OD between preand postimmune sera was determined at the same dilution. Data were expressed as the change in OD for each mouse. In some experiments (see Fig. 6), the mean change in OD for the group of nonimmunized controls was subtracted from that of the immunized mice.

Bronchoalveolar lavage $(B A L)$. BAL was performed as described previously (42). Briefly, trachea were surgically exposed and a small incision was made proximal to the carina. A 19-gauge tubing adapter was introduced into the trachea, secured with sutures, and the lungs were lavaged twice with $1 \mathrm{ml}$ of PBS/0.6 mM EDTA. Total cells were counted and cytospin preparations were prepared for Wright-Giemsa staining. Eosinophils were identified by the usual histologic criteria.

After lavage, lungs were reinflated with $10 \%$ phosphate-buffered formalin and placed in a container with the same fixative. Lungs were then embedded in paraffin and sectioned. Lung sections were stained with hematoxylin and eosin and examined microscopically for evidence of inflammation.

Eotaxin- and $\mathrm{KC}$-induced inflammatory responses. Peritoneal eosinophilia was induced by intraperitoneal administration of eosinophil-chemoattractant eotaxin. Mice were injected with $2 \mathrm{nM}$ LHVS or DMSO as above for $14 \mathrm{~d}$ (three mice in each group). The day after the last injection they were treated with $2 \mu \mathrm{g}$ eotaxin intraperitoneally. Mouse recombinant eotaxin was a gift of Dr. Giu-Quin Jia (Millennium Pharmaceuticals, Cambridge, MA). After $2 \mathrm{~h}$ the mice were killed as above and lavage was performed by instillation and removal of $10 \mathrm{~cm}^{3}$ RPMI from the peritoneal cavity. Total eosinophil counts were performed by analysis of the lavage fluid as described above.

Pulmonary inflammation and neutrophilia were induced by nasal insufflation of neutrophil chemokine KC (43). Recombinant mouse KC was a gift of Dr. David Waltz (Children's Hospital, Boston, MA). After a 14-d treatment with LHVS or vehicle, mice were anesthetized with $5 \%$ halothane, and $1.5 \mu \mathrm{g} \mathrm{KC}$ in $50 \mu \mathrm{l}$ PBS nasally instilled. $4 \mathrm{~h}$ after nasal insufflation of $\mathrm{KC}$, mice were killed and $\mathrm{BAL}$ was performed as above. Neutrophils were identified after Giemsa staining by the usual histologic criteria.

\section{Results}

Cathepsin $S$ and antigen presentation and processing in A20 cells. Cathepsin $\mathrm{S}$ is essential for efficient processing of Ii from class II-Ii complexes, to permit subsequent class II-peptide association in human B cells and murine splenocytes $(27,28)$. Will this biochemical alteration in Ii processing lead to a functional deficit in antigen presentation? Moreover, will inhibition of cathepsin S block generation of the antigenic peptide? To address these important issues, antigen processing and presentation after specific inhibition of cathepsin $\mathrm{S}$ were examined in the A20 murine B cells.

The cysteine protease profile of A20 cells was determined 
A

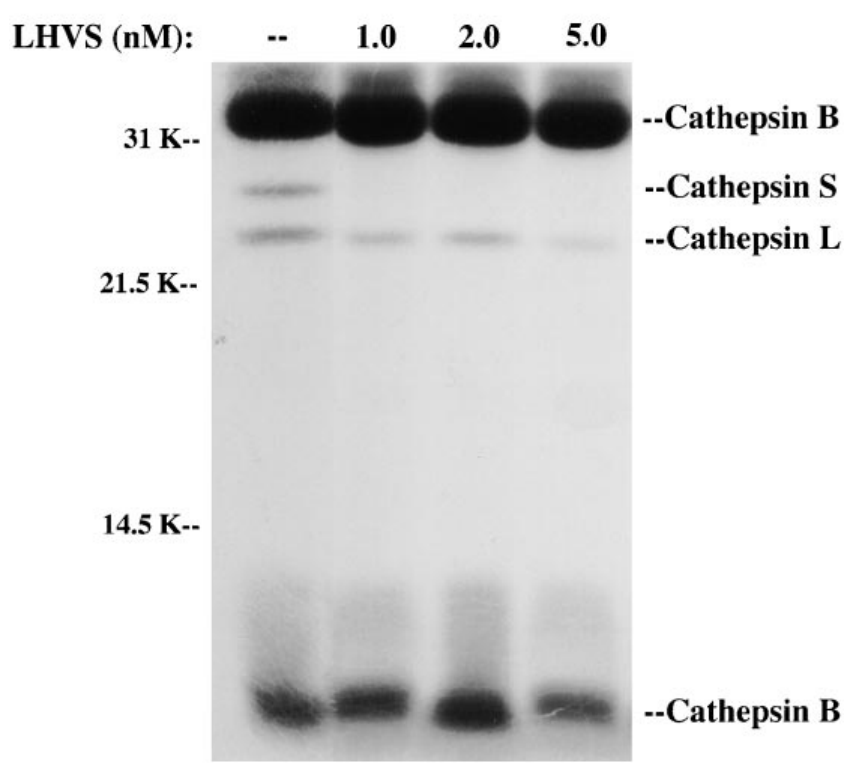

B

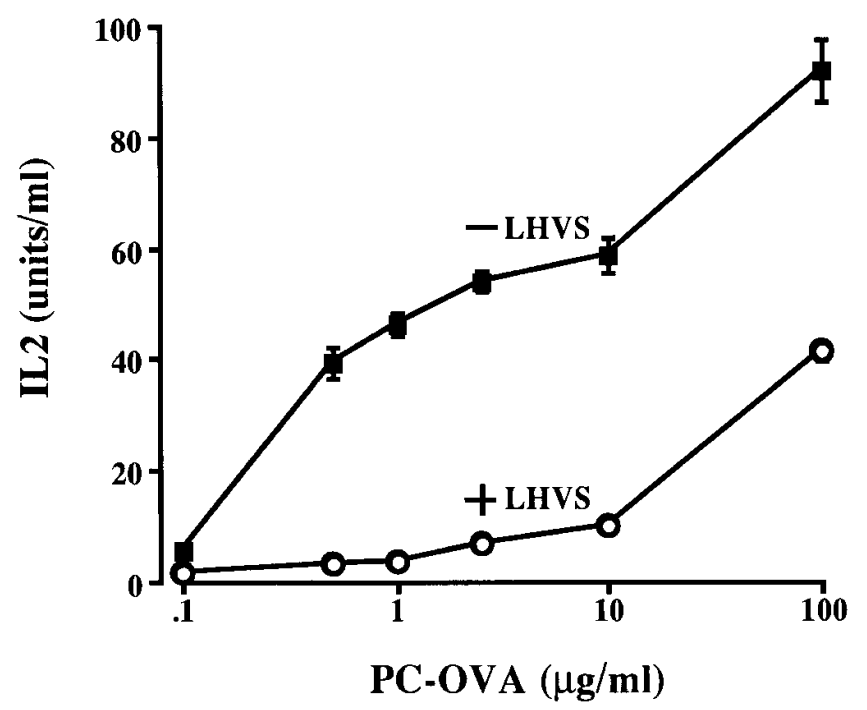

C

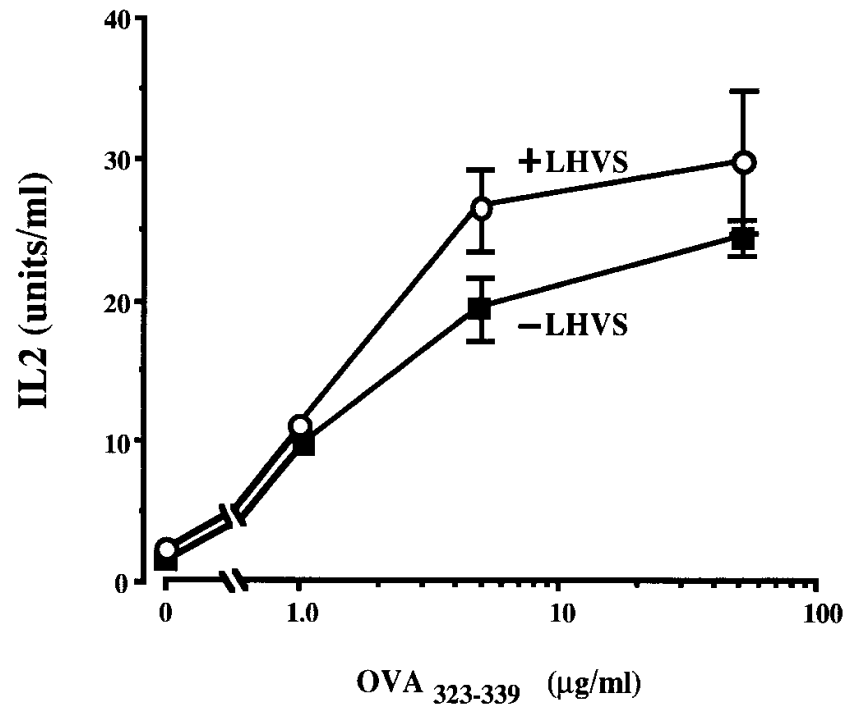

by incubation with the cysteine-class protease inhibitor Cbz$\left[{ }^{125} \mathrm{I}\right]-\mathrm{Tyr}-\mathrm{Ala}-\mathrm{CN}_{2}$ (Fig. $1 \mathrm{~A}$ ). As previously described (27), Cbz-[ $\left.{ }^{125} \mathrm{I}\right]-\mathrm{Tyr}-\mathrm{Ala}-\mathrm{CN}_{2}$ irreversibly binds to the active site of many cysteine proteases in proportion to their activity, and can be visualized by analysis on SDS-PAGE. Cysteine proteases within a cell that are first inactivated by other cysteine protease inhibitors, in this case the selective cathepsin $\mathrm{S}$ inhibitor LHVS, before incubation with Cbz-[ $\left.{ }^{125} \mathrm{I}\right]-\mathrm{Tyr}-\mathrm{Ala}-\mathrm{CN}_{2}$ do not label. A20 cells contain three cysteine proteases labeled by the active site inhibitor Cbz-[ $\left.{ }^{[25} \mathrm{I}\right]-\mathrm{Tyr}-\mathrm{Ala}-\mathrm{CN}_{2}$ : cathepsin $\mathrm{B}$ running at $32 \mathrm{kD}$ (single chain form) and $6 \mathrm{kD}$ (light chain form), cathepsin S running at $28 \mathrm{kD}$, and cathepsin L running at $24 \mathrm{kD}$ (Fig. $1 \mathrm{~A}$, first lane). The identities of these bands were confirmed by immunoprecipitation with specific antisera (data not shown). Prior incubation of A20 cells with low concentrations of LHVS produced a slightly different labeling pattern (Fig.
Figure 1. Specific inhibition of cathepsin $\mathrm{S}$ blocks antigen presentation in A20 cells. (A) A20 cells transfected with PC-specific human $\mu$ heavy chain were active site labeled with cysteine protease inhibitor Cbz$\left[{ }^{125} \mathrm{I}\right]$-Tyr-Ala- $\mathrm{CN}_{2}$ after incubation with selective cathepsin $\mathrm{S}$ inhibitor, LHVS. Cells were lysed and analyzed by $12 \%$ SDS-PAGE. (B) A20 cells were incubated with PC-OVA and DO.11 T cell hybridoma in the presence of $2 \mathrm{nM}$ LHVS $(+L H V S)$ or vehicle $(-L H V S)$. IL-2 generation was assayed in the supernatant after $24 \mathrm{~h}$. (C) A20 cells were fixed in $1 \%$ paraformaldehyde-PBS for $30 \mathrm{~min}$ at room temperature, washed, and then incubated with $\mathrm{OVA}_{323-339}$ peptide in the presence of $2 \mathrm{nM}$ LHVS $(+L H V S)$ or vehicle $(-L H V S)$. IL-2 generation was assayed in the supernatant after $24 \mathrm{~h}$. Each data point in $B$ and $C$ represents the mean \pm SEM of three wells in a 96-well plate.

$1 A$, second through fourth lanes). LHVS at 1 and $2 \mathrm{nM}$ inhibited cathepsin S alone, whereas LHVS at $5 \mathrm{nM}$ began to attenuate the activity of cathepsin L. Thus, low concentrations of LHVS (1-2 nM) can be used to specifically inhibit cathepsin S activity in A20 cells.

To determine if specific inhibition of cathepsin S activity can functionally alter antigen presentation, A20 cells transfected with surface immunoglobulin against PC were incubated with PC-OVA in the absence and presence of $2 \mathrm{nM}$ LHVS. Antigen presentation was assessed by stimulation of OVA-specific T cell clone DO.11.10. This hybridoma can react to OVA or OVA peptide (residues 323-339) presented by class II molecules of either $\mathrm{H}-2^{\mathrm{d}}$ or $\mathrm{H}-2^{\mathrm{b}}$ haplotype (34). Inhibition of cathepsin $\mathrm{S}$ had a profound effect on the ability of A20 cells to present OVA (Fig. $1 B$ ). To examine whether LHVS alters $\mathrm{T}$ cell proliferation independently of antigen presentation, 
fixed A20 cells were incubated with $\mathrm{OVA}_{323-339}$ peptide and DO.11 cells in the presence $(+L H V S)$ and absence $(-L H V S)$ of $2 \mathrm{nM}$ LHVS (Fig. $1 C$ ). Antigen presentation in this model occurs via surface displacement of class II-bound peptides by $\mathrm{OVA}_{323-339}$, and is independent of Ii and antigen processing. LHVS had no effect on the ability of $\mathrm{T}$ cells to respond to OVA $_{323-339}$ peptide presented by fixed A20 cells. Thus, specific inhibition of cathepsin $\mathrm{S}$ in mouse B cells markedly attenuates antigen presentation of an immunodominant OVA peptide.

We next determined if inhibition of cathepsin S blocks generation of the antigenic epitope, or rather blocks the ability of the antigenic peptides to associate with class II molecules. The latter paradigm is most consistent with the biochemical alterations observed in human B lymphoblasts after inhibition of cathepsin S (27). A20 cells were incubated with PC-OVA for 15-30 min in the absence (Fig. 2, left) or presence (Fig. 2, right) of 2 nM LHVS, lysed, and centrifuged over a Percoll gradient to separate intracellular compartments based on their intrinsic densities. Incubation of A20 cells with LHVS in this assay did not alter antigen uptake as evidenced by the distribution of human $\mu$ chain, nor did it alter the distribution of class II molecules, plasma membrane marker, or lysosomal marker (Fig. 2, $A$ and $B$ ). The Percoll fractions were then collected and the presence of antigenic material was assessed in each fraction by $\mathrm{T}$ cell hybridoma stimulation by fixed APCs which do (M12.4.1) or do not (M12.C.3) express MHC class II molecules. Subcellular fractions containing processed peptide or class II-peptide complexes (total peptide) will stimulate T cells when incubated with presenting cells expressing class II molecules (M12.4.1). Alternatively, only those fractions containing class II-peptide complexes will stimulate $\mathrm{T}$ cells when incubated with presenting cells not expressing class II molecules
$\mathbf{A}$

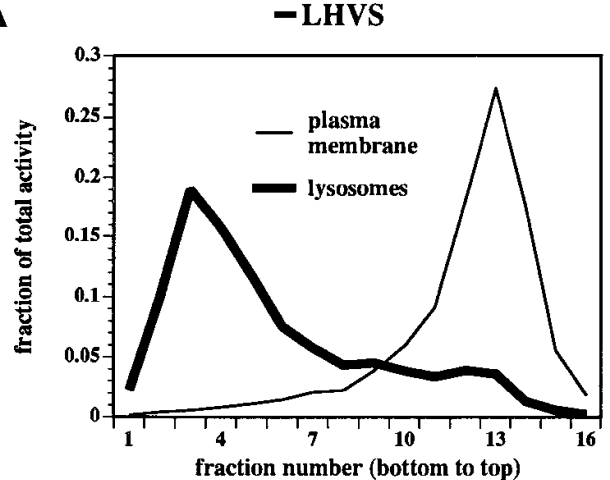

B

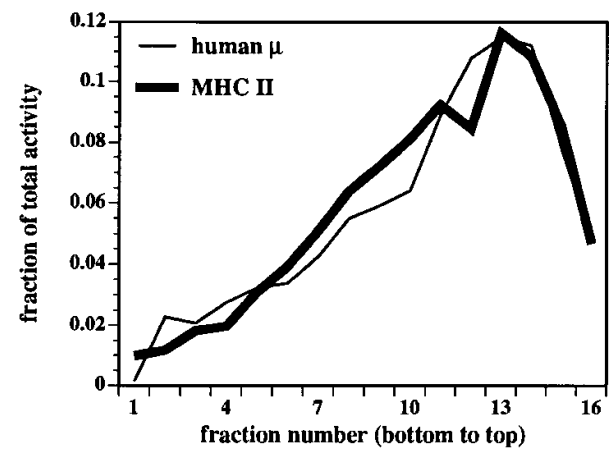

C

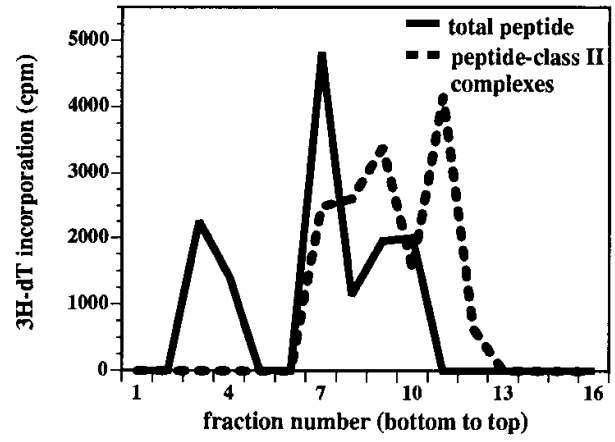

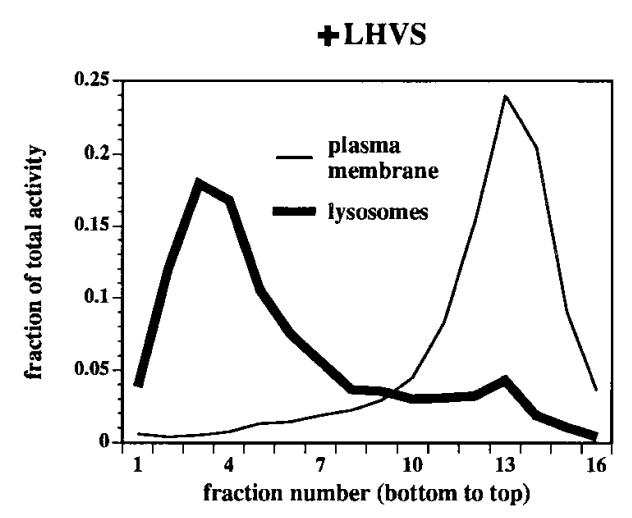
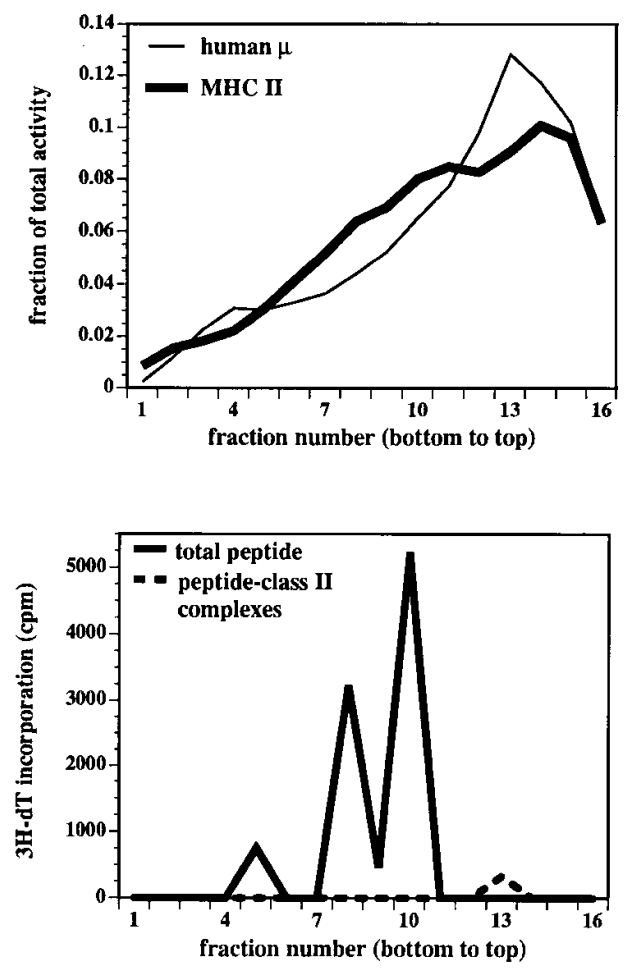

Figure 2. Inhibition of cathepsin S prevents class II-peptide association, and not generation of antigenic peptide. A20 cells were incubated with PC-OVA at $100 \mu \mathrm{g} / \mathrm{ml}$ for $15-30 \mathrm{~min}$ at $37^{\circ} \mathrm{C}$, in the presence of $2 \mathrm{nM}$ LHVS (right) or vehicle (left). Cells were ruptured by nitrogen cavitation and fractionated over a Percoll gradient. Fraction 1 represents the highest density and fraction 16 the lowest. $(A)$ Distributions of plasma membrane marker ADPE I (thin line) and lysosomal marker $\beta$-hexosaminidase (thick line). (B) Distributions of human $\mu$ heavy chain (thin line) and MHC class II molecules (thick line). (C) Fractions were sonicated and incubated with paraformaldehyde-fixed M12.4.1 class $\mathrm{II}^{+}$(thick line) or M12.C.3 class II $^{-}$APCs (dashed line) and washed. APCs were then incubated in triplicate with DO.11 cells to assay for total peptide (free and class II-associated) present in fractions (thick line), or for peptide only bound to class II molecules (dashed line). IL-2 secretion was assayed in the supernatant after $24 \mathrm{~h}$. Peptide was generated in endosomal compartments (fractions 7-11) in both control (left) and inhibited cells (right). However, antigenic peptide was unable to associate with class II molecules in the LHVS-treated cells. Fixed APCs incubated with medium or OVA produced background counts of $\sim 500 \mathrm{cpm}$. This background was subtracted from all tested fractions. $\mathrm{OVA}_{323-339}$ incubated with M12.4.1 class $\mathrm{II}^{+}$ APCs resulted in 8,565 cpm. 
(M12.C.3). Consistent with previous studies (37), uninhibited A20 cells were able to generate peptide in lysosomal compartments (fractions 2-5) and endosomes (fractions 7-11) (Fig. $2 C$ ). Class II-peptide complexes were primarily generated in the nonlysosomal, endosomal compartments. After specific inhibition of cathepsin S with LHVS, A20 cells were able to generate antigenic OVA fragments in these compartments (Fig. $2 C$ ). However, these same fractions were completely devoid of class II-peptide complexes, implying that the generated peptide is unable to associate with class II molecules. Thus, cathepsin $\mathrm{S}$ is necessary to render class II molecules competent for binding peptide, but does not qualitatively alter generation of OVA peptide with the capacity to stimulate DO.11 cells in the presence of class II molecules. This is consistent with its role as the protease primarily responsible for Ii processing in both human and murine APCs.

Inhibition of cathepsin $S$ in vivo. Since inhibition of cathepsin S can block Ii processing $(27,28)$ and antigen presentation
A

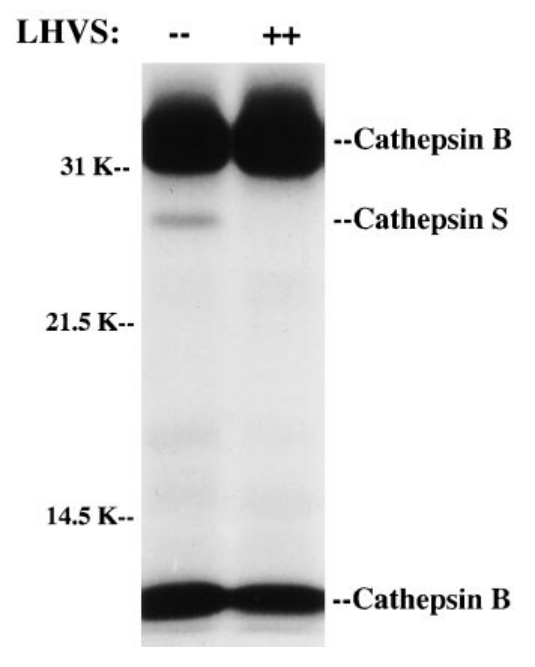

B

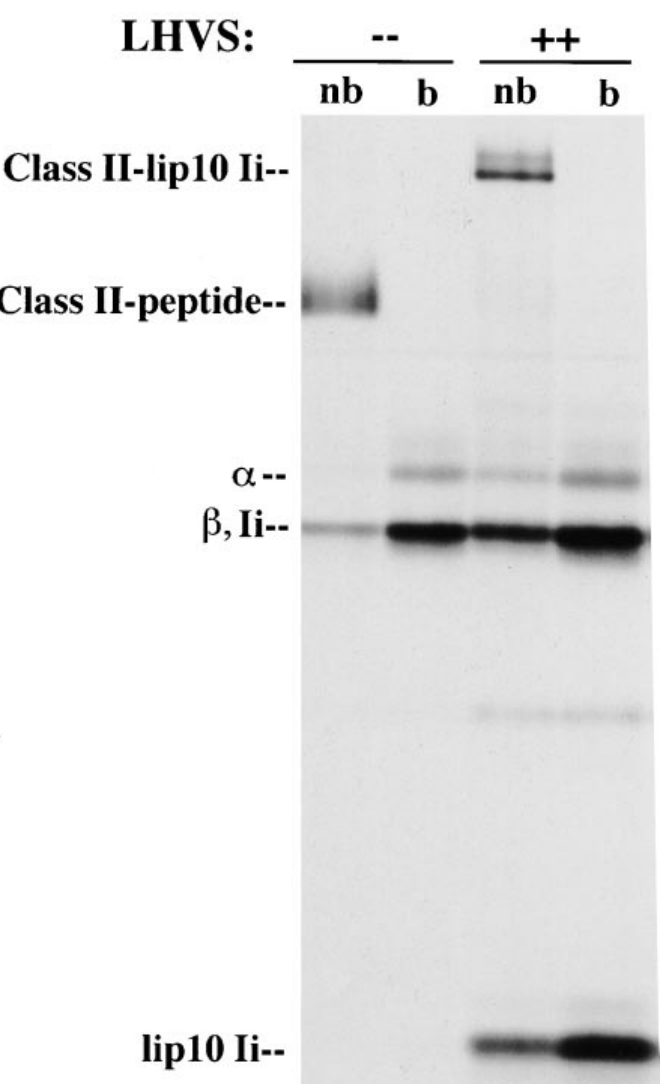

Figure 3. LHVS can be used in vivo to selectively inhibit cathepsin S activity and disrupt Ii processing, class II-peptide complex formation, and antigen presentation. $(A)$ Active site label of mouse spleen cells after injection of $100 \mathrm{mg} / \mathrm{kg}$ LHVS every $48 \mathrm{~h}$ for $14 \mathrm{~d}$. C57BL/6 mouse spleen cells (10 million cells/sample) were incubated with Cbz$\left.{ }^{125} \mathrm{I}\right]-\mathrm{Tyr}-\mathrm{Ala}-\mathrm{CN}_{2}$ for $1 \mathrm{~h}$ at $37^{\circ} \mathrm{C}$, lysed, and analyzed on $12 \%$ SDSPAGE. There was no LHVS present in the medium during labeling with Cbz$\left[{ }^{125} \mathrm{I}\right]-\mathrm{Tyr}-\mathrm{Ala}-\mathrm{CN}_{2}$. (B) Class II-Ii processing of C57BL/6 (I-A $\left.{ }^{\mathrm{b}}\right)$ mouse spleen cells after intraperitoneal injection of LHVS. Mice were injected with $100 \mathrm{mg} / \mathrm{kg}$ LHVS (or vehicle) intraperitoneally every $48 \mathrm{~h}$ for $14 \mathrm{~d}$. $2 \mathrm{~d}$ after the last injection spleen cells (20 million $/ \mathrm{ml}$ ) were harvested and preincubated in methionine, cysteine-free DME for $1 \mathrm{~h}$, followed by pulse labeling with $1 \mathrm{mCi}\left[{ }^{35} \mathrm{~S}\right]$ methionine, cysteine for $1 \mathrm{~h}$. Cells were washed and chased for $4 \mathrm{~h}$ in RPMI $/ 10 \%$ FBS. There was no LHVS present in the medium during this pulse-chase experiment. Cells were lysed and class II molecules were immunoprecipitated with $\mathrm{mAb}$ N22. Pellets from each sample were divided in half and analyzed under mildly denaturing (nonreducing) conditions, both boiled $(b)$ and nonboiled $(n b)$, on $12 \%$ SDS-PAGE. $(C)$ Antigen presentation of OVA by mouse spleen cells after in vivo treatment with LHVS. C57BL/6 mice were injected every $48 \mathrm{~h}$ for $14 \mathrm{~d}$ with either $100 \mathrm{mg} / \mathrm{kg}$ LHVS or vehicle. The day after the last injection, spleen cells were harvested and incubated at $2 \times 10^{5}$ cells/well with OVA and $10^{5}$ cells/ well T cell hybridoma DO.11. IL-2 production was assayed in the supernatant after $24 \mathrm{~h}$. There was no LHVS present in the medium during the assay. All samples were run in triplicate. Each data point represents the mean \pm SEM of splenocytes from four animals. 
(Figs. 1 and 2) in professional APCs, selective targeting of cathepsin $\mathrm{S}$ activity in vivo is a tantalizing prospect for altering the immune response. Can cathepsin $\mathrm{S}$ activity be selectively blocked pharmacologically in vivo, and how will this alter the immune response? To study these questions C57BL/6 mice were injected intraperitoneally with the selective cathepsin S inhibitor LHVS. Cysteine protease activity after LHVS administration in splenocytes was assessed by incubation with Cbz$\left.{ }^{125} \mathrm{I}\right]-\mathrm{Tyr}-\mathrm{Ala}-\mathrm{CN}_{2}$. Time course experiments demonstrated that cathepsin $S$ remained fully inhibited for up to $48 \mathrm{~h}$ after a single injection of LHVS at $100 \mathrm{mg} / \mathrm{kg}$, whereas at $72 \mathrm{~h}$, recovery of activity was demonstrable (data not shown). Thus, selective inhibition of cathepsin $\mathrm{S}$ can be achieved by intraperitoneal administration of $100 \mathrm{mg} / \mathrm{kg}$ LHVS every $48 \mathrm{~h}$. Fig. $3 \mathrm{~A}$ shows the cysteine protease activity pattern of murine splenocytes after intraperitoneal injection of LHVS at $100 \mathrm{mg} / \mathrm{kg} \mathrm{ev-}$ ery $48 \mathrm{~h}$ for $14 \mathrm{~d}, 48 \mathrm{~h}$ after the final injection. Murine spleen cells primarily express two cysteine proteases labeled by the active site inhibitor Cbz-[ $\left.{ }^{125} \mathrm{I}\right]-\mathrm{Tyr}-\mathrm{Ala}-\mathrm{CN}_{2}$ : cathepsin $\mathrm{B}$ running at $32 \mathrm{kD}$ (single chain form) and $6 \mathrm{kD}$ (light chain form), and cathepsin $\mathrm{S}$ running at $28 \mathrm{kD}$ (Fig. $3 \mathrm{~A}$, first lane). The identities of these bands were confirmed by immunoprecipitation with specific antisera (data not shown). Cathepsin S, but not cathepsin B, activity was inhibited in spleen cells from mice injected with $100 \mathrm{mg} / \mathrm{kg}$ LHVS at $48 \mathrm{~h}$ after injection (Fig. $3 A$, second lane). This same pattern of cysteine protease activity was observed in alveolar macrophages obtained by BAL (data not shown).

In vivo administration of LHVS results in a marked alteration of Ii processing and class II-peptide complex formation (Fig. 3 B). Spleen cells from mice injected with $100 \mathrm{mg} / \mathrm{kg}$ LHVS (or vehicle) every $48 \mathrm{~h}$ for $14 \mathrm{~d}$ were harvested, pulselabeled for $1 \mathrm{~h}$, and chased for $4 \mathrm{~h}$. LHVS was not included during this pulse-chase experiment. The cells were then lysed and the class II molecules were immunoprecipitated with hamster mAb N22, which reacts against both Ii-associated and Iifree class II complexes $(28,32)$. Samples were analyzed by SDS-PAGE, with or without previous boiling, to evaluate the formation of SDS-stable class II-peptide complexes. Cells from mice injected with vehicle alone demonstrated the normal pattern of class II maturation (Fig. $3 \mathrm{~B}$, first and second lanes), with polypeptide bands corresponding to class II $\alpha$ and $\beta$ chains, and a higher molecular weight band in the nonboiled sample representing SDS-stable class II-peptide complexes (21). Intact Ii was observed migrating very close to the $\beta$ chain.
In contrast, spleen cells from mice injected with LHVS revealed a marked accumulation of class II-associated lip10 Ii fragment and a concomitant blockage of SDS-stable class IIpeptide complex generation (Fig. $3 \mathrm{~B}$, third and fourth lanes). The appearance of a larger molecular weight complex in the third lane of Fig. 3 represents accumulation of $\alpha \beta$-lip10 Ii, which only partially dissociates under these conditions (28). Thus, inhibition of cathepsin S by administration of LHVS in vivo inhibits complete degradation of Ii and subsequent formation of SDS-stable $\alpha \beta$-peptide complexes.

To determine if this biochemical Ii processing defect translates into a functional presentation deficit, spleen cells from LHVS-treated (or vehicle-treated) animals were used to process and present OVA to the T cell hybridoma DO.11. LHVS was absent during this presentation assay. Spleen cells from mice treated with LHVS demonstrated a clear functional deficit in antigen presentation (Fig. $3 \mathrm{C}$ ). Interestingly, inhibition of cathepsin S by administration of LHVS did not result in decreased expression of total class II (as determined by flow cytometry) or peptide-bound class II molecules (as analyzed by biotinylation and immunoprecipitation of surface MHC class II molecules) (data not shown). These data, together with the pulse-chase experiment (Fig. $3 \mathrm{~B}$ ), suggest that inhibition of cathepsin $\mathrm{S}$ delays, but does not completely block, formation of class II-peptide complexes.

To examine whether administration of LHVS for $2 \mathrm{wk}$ in vivo results in gross $\mathrm{T}$ cell dysfunction, spleen cells from mice treated with LHVS (or vehicle) were used as responding cells in PHA stimulation assays and in a mixed lymphocyte reaction with irradiated Balb/c spleen cells as stimulators. $\left[{ }^{3} \mathrm{H}\right]$ Thymidine uptake after stimulation by heterologous spleen cells or PHA was similar for both groups (Fig. 4).

Inhibition of cathepsin $S$ and immunity. What are the functional consequences of cathepsin $\mathrm{S}$ inhibition on the immune response? We compared the capacity of LHVS-treated and vehicle-treated animals to elicit an immune response in two different models of OVA-induced immunity. The first model assessed the ability of LHVS-treated animals to mount a humoral immune response when challenged with OVA in the presence of CFA. The second model looked at the ability of LHVS-treated animals to elicit a pulmonary inflammatory and hypersensitivity response when sensitized by intraperitoneal administration of alum-precipitated OVA, and subsequently challenged with nebulized OVA.

In the first model, C57BL/6 mice were injected with LHVS,

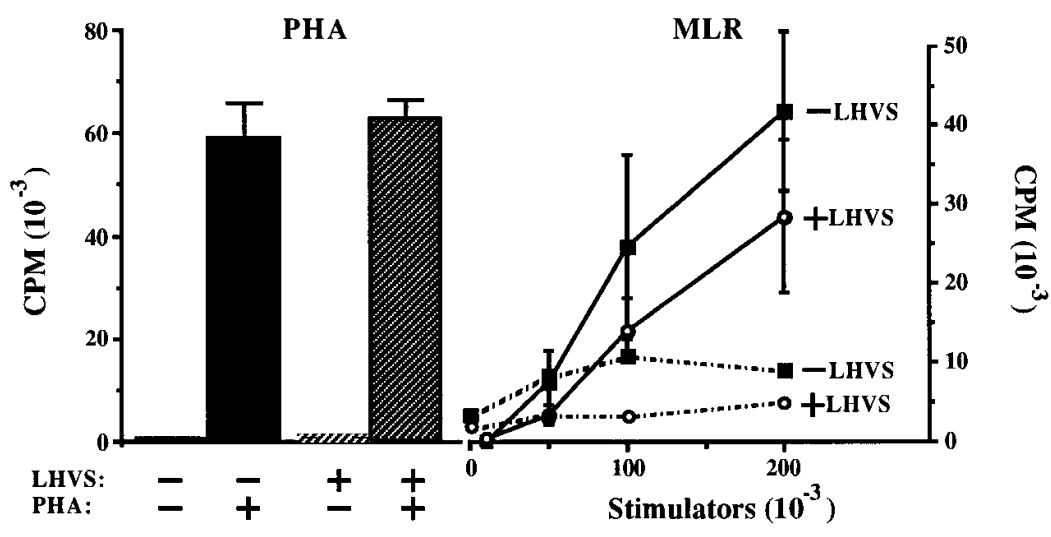

Figure 4. Spleen cells from mice treated with LHVS exhibit a normal response to PHA and heterologous spleen cells. C57BL/6 mice were injected with $100 \mathrm{mg} /$ $\mathrm{kg}$ LHVS every $48 \mathrm{~h}$ for $2 \mathrm{wk}$. The day after the last injection spleen cells were harvested and aliquoted into microtiter plates at $2 \times 10^{5}$ cells/well. These cells were then stimulated with either PHA $(10 \mu \mathrm{g} / \mathrm{ml})$ or irradiated Balb/c (I-A $\mathrm{A}^{\mathrm{d}}$ ) spleen cells (stimulators) for $72 \mathrm{~h}$ and $6 \mathrm{~d}$, respectively. Each data point represents the mean \pm SEM of splenocytes from four animals. Dashed lines represent the mean of two spleens incubated with syngeneic C57BL/6 as stimulators. Inhibitor ( $2 \mathrm{nM}$ LHVS) was present in the supernatant of spleen cells from mice treated in vivo with LHVS. All samples were run in triplicate. 
A

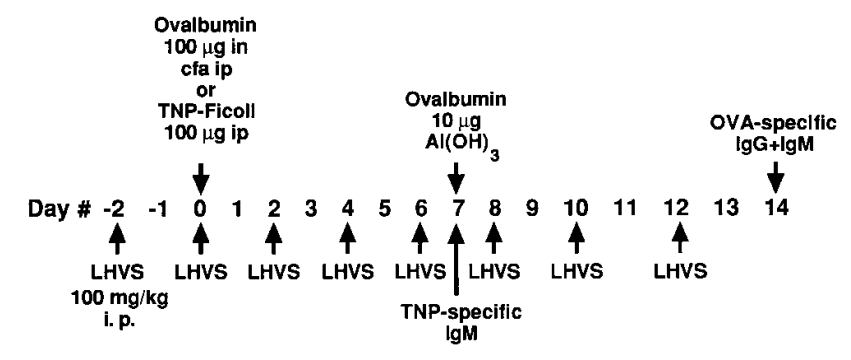

C

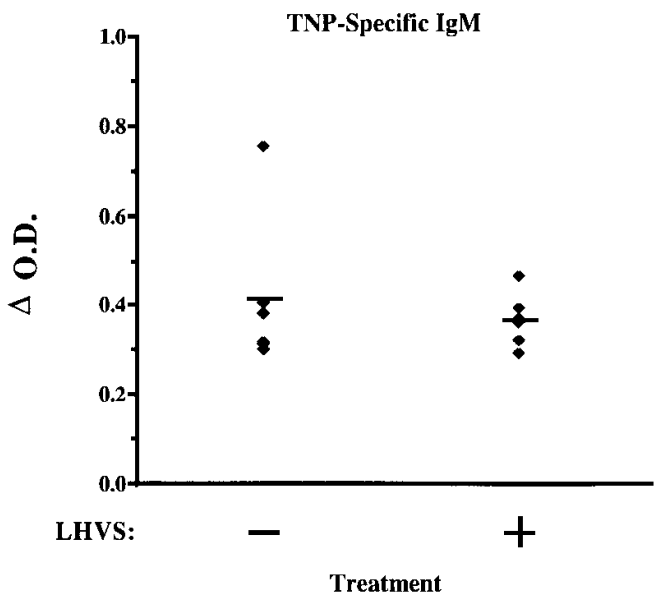

B

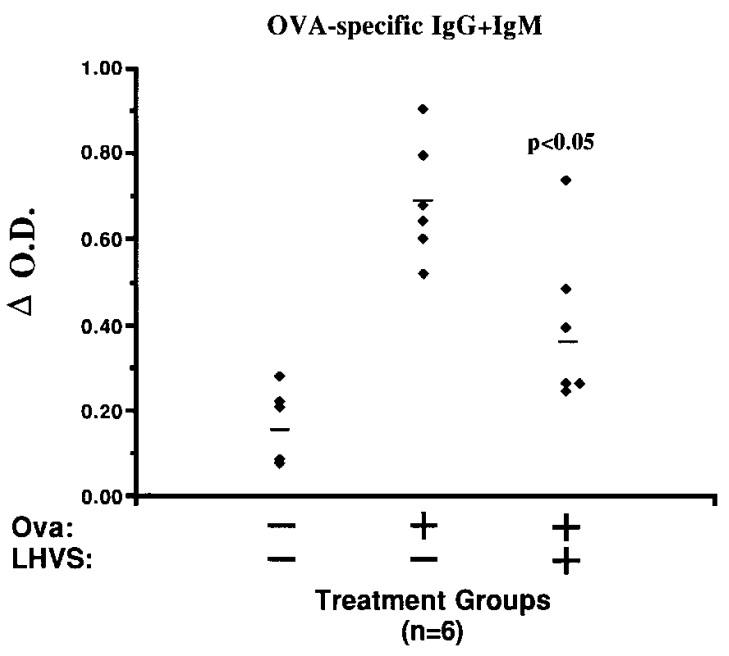

Figure 5. Selective inhibition of cysteine proteases in vivo alters a primary immune response to OVA. (A) Schematic illustration of the immunization protocol and LHVS administration used. (B) C57BL/6 mice were immunized as shown in $A$. Preand postimmune sera were collected, diluted $1: 100$ with PBS/1\% BSA, and OVAspecific IgG + IgM measured by ELISA as described in Methods. Each treatment group consisted of six mice. Data analysis was performed by ANOVA with Tukey's multiple comparison test. $(C)$ Separate C57BL/6 mice were immunized intraperitoneally with $100 \mu \mathrm{g}$ T cell-independent antigen TNP-Ficoll. Pre- and postimmune (7 d) sera were collected, diluted 1:500 with PBS/1\% BSA, and TNP-specific IgM was measured as described in Methods. Each treatment group consisted of six mice. or vehicle alone, every $48 \mathrm{~h}$ for 2 wk starting on day -2 (Fig. $5 A$ ). An immune response was elicited by intraperitoneal injection of OVA in CFA at day 0 with boost administered at day 7. Pre- and postimmune sera were collected and OVAspecific $\operatorname{IgG}+\operatorname{IgM}$ antibody titers determined by ELISA. Inhibition of cathepsin $\mathrm{S}$ resulted in a reduction, but not total abrogation, of the humoral immune response (Fig. $5 \mathrm{~B}$ ). Only one animal treated with LHVS responded normally to OVA. The reason for this deviation is presently unclear, but could be related to uneven administration of the inhibitor, or cellular compensatory mechanisms during long-term inhibition of cathepsin S. To examine the functionality of B cells in LHVStreated mice independent of antigen processing and presentation, mice were injected with T cell-independent antigen TNPFicoll, and TNP-specific IgM production measured after $1 \mathrm{wk}$ (Fig. 5 C) (39). There was no difference in generation of TNP-specific IgM between the LHVS-treated and vehicle (DMSO)-treated animals. Thus, inhibition of cathepsin S by administration of LHVS significantly alters antigen presentation-dependent antibody production without affecting the ability of B cells to respond to a T cell-independent antigen.

To examine the immune response in an alternative animal model, pulmonary inflammation and hypersensitivity were induced in mice as described previously (Fig. $6 A$ ) $(40,41)$. Briefly, mice were sensitized by two intraperitoneal injections of OVA conjugated to aluminum hydroxide gel $5 \mathrm{~d}$ apart. On day 12 mice were exposed to nebulized OVA for $2 \mathrm{~h} .3 \mathrm{~d}$ after nebulization, sera were obtained for IgE titers and BALs were performed for evidence of eosinophilia. This model has been characterized extensively and produces a brisk $\operatorname{IgE}$ response in the serum, and a perivascular eosinophilic infiltration in the lung, evidence of pulmonary hypersensitivity, and inflammation (40, 41). LHVS (or vehicle) was administered beginning $2 \mathrm{~d}$ before the initial immunization and every $48 \mathrm{~h}$ thereafter. Control mice (3-4/experiment) were not sensitized with intraperitoneal injection of OVA but were exposed to nebulized OVA.

Selective inhibition of cathepsin S mitigates both the generation of antibody titers and the hypersensitivity inflammatory reaction in the lung. LHVS attenuated the development of OVA-specific IgG + IgM titers (Fig. $6 B$ ) and total IgE titers (Fig. $6 C$ ). Further evidence of functionally important immune sequelae produced by inhibition of cathepsin $S$ is shown by analysis of eosinophils in the BALs (Fig. $6 D$ ). The BALs from mice not sensitized with OVA had normal numbers of alveolar macrophages $\left(350 \times 10^{3}\right)$, but no eosinophils. Sensitization and inhalation with OVA in control animals resulted in a marked influx of eosinophils in BAL fluid ( $>50 \%$ ) (Fig. $6 \mathrm{D}$ ), with a small but significant increase in polymorphonuclear granulocytes and lymphocytes (data not shown). Treatment with LHVS profoundly blocked these inflammatory changes as reflected by the near absence of eosinophils in the BAL fluid (Fig. $6 \mathrm{D}$ ). Histological sections of lungs from control mice show a prominent perivascular infiltration of inflammatory cells, which is blocked by treatment with LHVS (compare Fig. $7 B$ with $C$ ).

To determine whether LHVS nonspecifically inhibits eosinophil migration or pulmonary inflammation, two antigen-inde- 
A

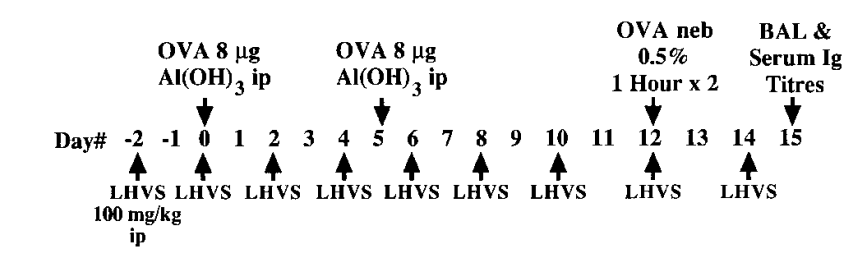

B

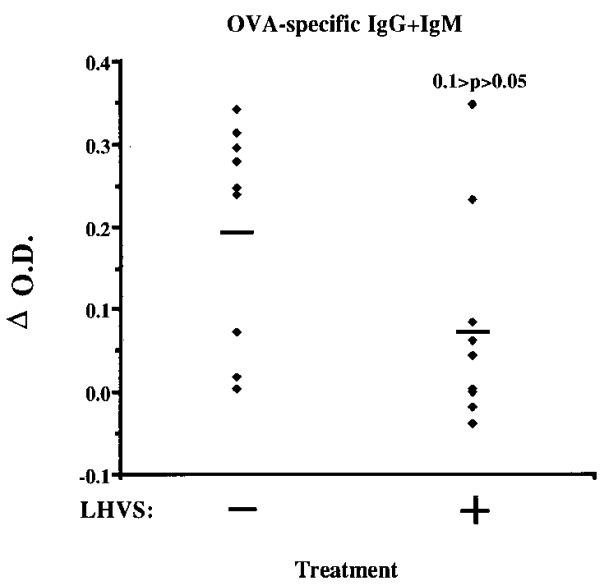

C

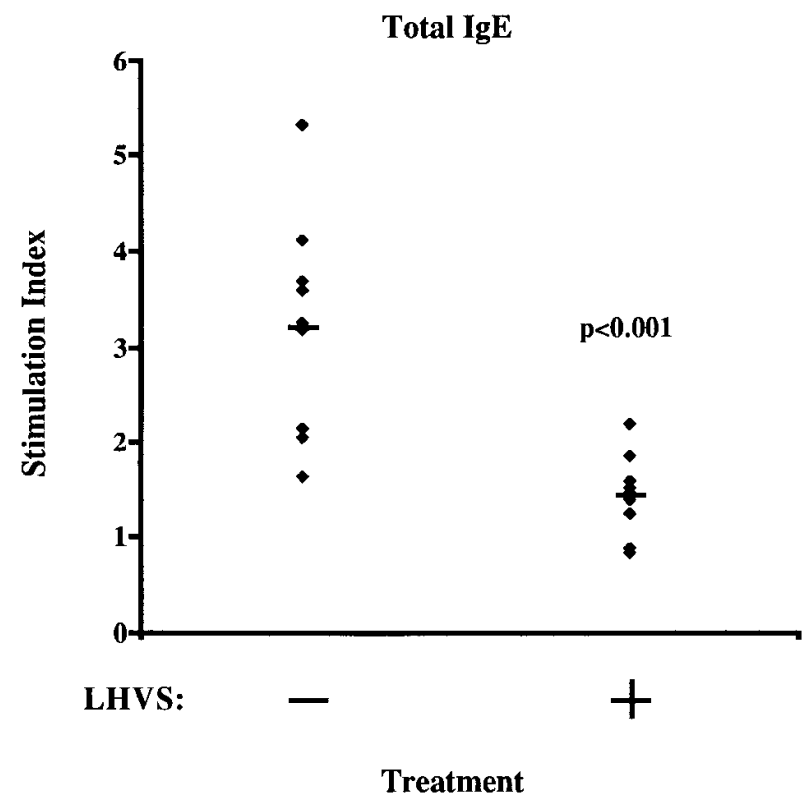

D

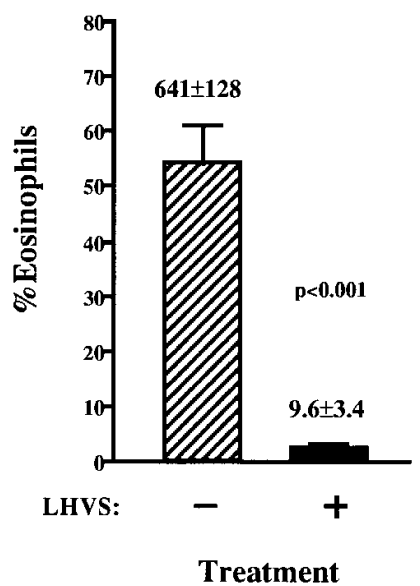

Figure 6. Selective inhibition of cysteine proteases in vivo attenuates $\operatorname{IgE}$ titers and blocks BAL eosinophilia in a murine model of OVA-induced pulmonary hypersensitivity. ( $A$ ) Schematic illustration of the immunization protocol used and LHVS administration. (B) OVA-specific IgG + IgM titers from sera (diluted $1: 100$ in PBS/1\% BSA) of immunized animals after treatment with vehicle (DMSO) or LHVS. Data represent pooling of two separate experiments. $\Delta \mathrm{OD}$ was calculated by subtract-

ing the mean OD of control mice ( $n=4$ in the first experiment and $n=3$ in the second) from vehicle- or LHVS-injected mice ( $n=4$ in the first experiment and $n=5$ in the second). Horizontal bar represents the mean of each treatment group. $(C)$ Serum IgE titers from OVA-immunized mice treated with vehicle or LHVS. Sera from all animals were diluted 1:20 in PBS/1\% BSA. Animals are the same as in $B$. Stimulation indices were calculated by dividing the vehicle- and LHVS-treated IgE levels by mean levels from control mice in each experiment. $(D)$ Percent eosinophils in BAL from immunized mice after treatment with vehicle alone or LHVS. BALs were performed on mice as described in Methods. Cells were counted, and cytospin samples were prepared and stained with Giemsa stain. Eosinophils were identified by normal cytological criteria. Data from two experiments, as in $B$ and $C$, were pooled. There were no eosinophils in the control group. Statistical analyses in $B, C$, and $D$ were done by Student's $t$ test. Numbers above bars represent total eosinophil number \pm SEM $\left(10^{-3}\right)$ in each experimental group.

pendent models of cytokine-induced inflammatory reactions were used. In the first model, intraperitoneal administration of eotaxin induced peritoneal eosinophilia in both vehicle- and LHVS-treated animals. The mean $( \pm$ SEM) peritoneal eosinophil count per animal was $2.55( \pm 0.46) \times 10^{6}$ in vehicle-treated mice and $2.40( \pm 1.0) \times 10^{6}$ in LHVS-treated mice $(n=3$ in both groups). There were no eosinophils in peritoneal lavages from control mice. $\mathrm{KC}$ is an $\alpha$-chemokine able to induce a potent, neutrophilic pulmonary reaction by tracheal instillation in a rat model of pulmonary inflammation $(43,44)$. Similarly, we are able to induce an exuberant, neutrophilic pulmonary inflammatory reaction in mice by nasal insufflation of $1.5 \mu \mathrm{g}$ of $\mathrm{KC}$ (our unpublished observations). LHVS did not abrogate this reaction when compared with vehicle-treated mice: there were $14.5 \times 10^{6}$ neutrophils/animal in BAL fluid from LHVStreated animals, and $7.7 \times 10^{6}$ neutrophils/animal in BAL fluid from DMSO-treated mice.

\section{Discussion}

This manuscript presents the first direct evidence that selective inhibition of cysteine proteases in vivo has important func- 

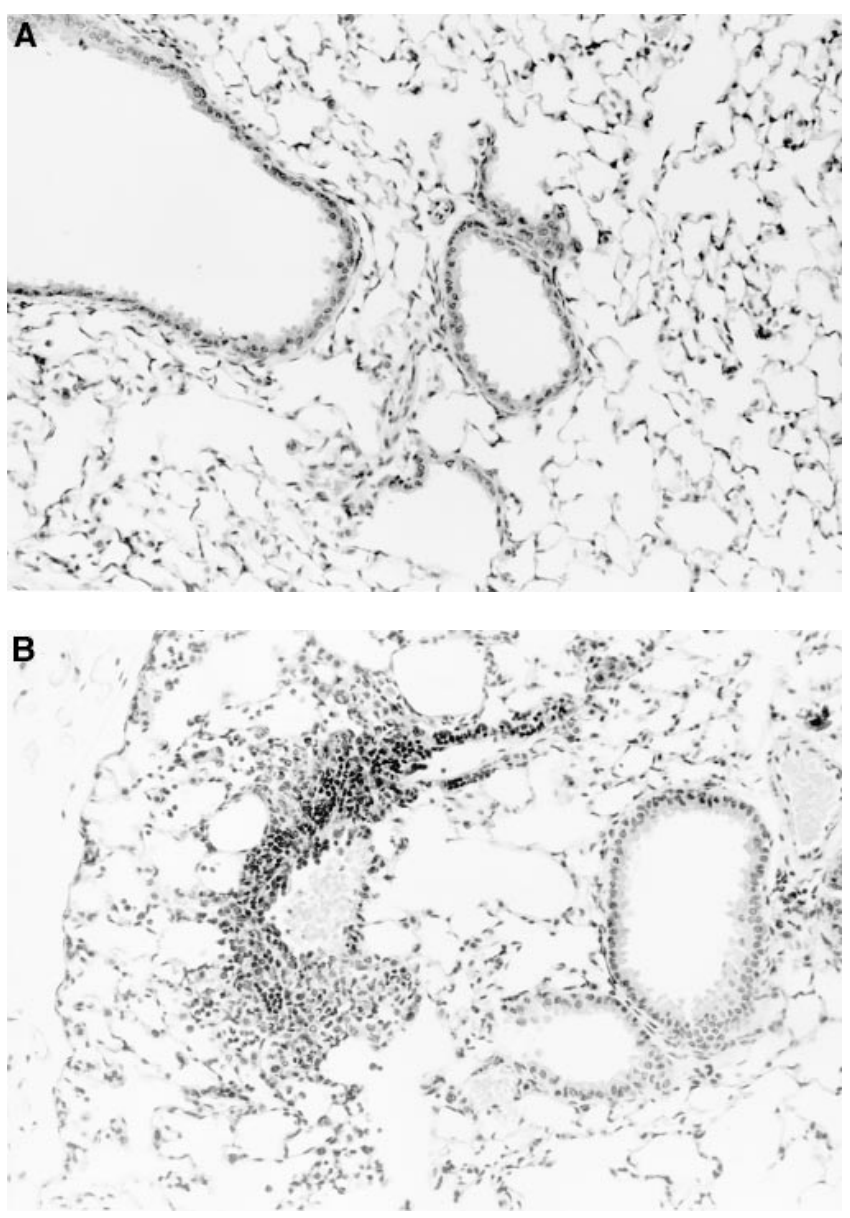

tional consequences for MHC class II-dependent immune responses. Several lines of evidence lead us to conclude that the mechanism underlying the immune modulating effects of cathepsin $\mathrm{S}$ inhibition is most likely secondary to alterations in class II-Ii processing and subsequent peptide loading. First, specific inhibition of cathepsin S in a B cell line (A20) leads to a profound inhibition in presentation of an OVA peptide (Figs. 1 and 2). This antigen presentation defect results from an inability of antigenic peptide to associate with class II molecules, and is not a consequence of a defect in antigen processing. This is consistent with the previous finding that leupeptin, a nonspecific cysteine protease inhibitor, inhibits presentation of this OVA peptide in A20 cells (45). Second, when administered in vivo, LHVS produces marked alterations in splenocyte MHC class II-Ii processing, peptide loading, and antigen presentation (Fig. 3). This is consistent with alterations of class II-Ii processing produced by inhibition of cathepsin $\mathrm{S}$ in $\mathrm{mu}-$ rine splenocytes ex vivo (28). Third, splenic T cells from mice treated with LHVS responded well when stimulated by PHA or in a mixed lymphocyte reaction, making gross $\mathrm{T}$ cell dysfunction an unlikely explanation for our data (Fig. 4). Finally, LHVS did not appreciably alter the inflammatory reaction in three antigen-independent models of inflammation ( $\mathrm{T}$ cellindependent antigen immunization; eotaxin-induced peritoneal eosinophilia; KC-induced pulmonary neutrophilia). Together, these data support the hypothesis that cathepsin S,

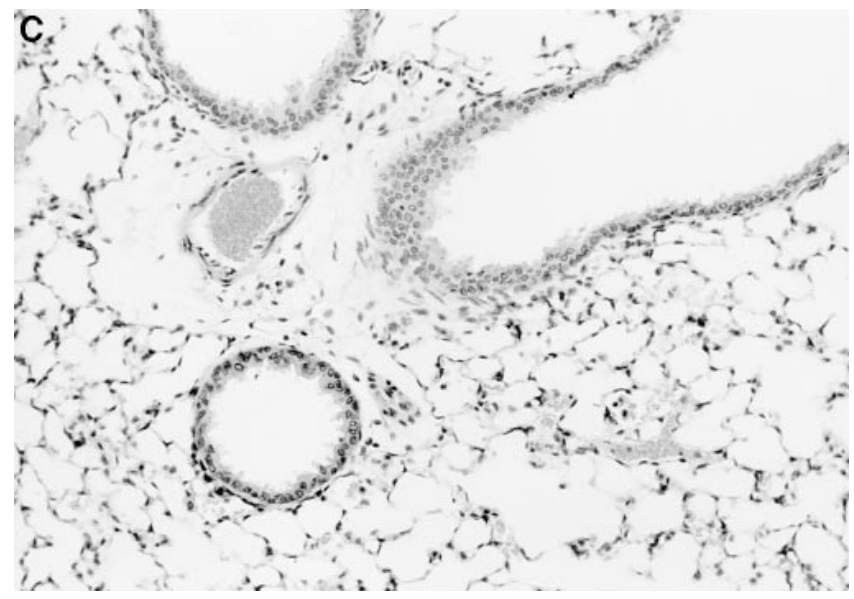

Figure 7. In vivo administration of LHVS blocks perivascular inflammatory cell infiltration in OVA-induced pulmonary hypersensitivity. $(A)$ Histological examination of murine lung sections from mice which were not sensitized to intraperitoneal OVA, but were exposed to nebulized OVA as a negative control. (B) Lung sections from mice sensitized and exposed to OVA demonstrating a prominent perivascular inflammatory cell infiltration. This is consistent with previous reports showing a prominent perivascular, eosinophilic infiltration in the lungs of mice using this model of pulmonary hypersensitivity $(40,41)$. (C) Lung sections from mice sensitized and exposed to OVA as in $B$ after treatment with LHVS (protocol as in Fig. $4 A$ ). Selective inhibition of LHVS profoundly blocked the perivascular inflammatory response.

previously shown to be important in Ii processing in vitro, regulates MHC class II function and subsequent immune responses in vivo.

Although pulse-chase experiments revealed a marked defect in Ii processing and class II-peptide binding of freshly isolated splenocytes deficient in cathepsin $S$, in vivo inhibition of cathepsin S did not completely ablate the humoral response to OVA (Figs. 5 and 6). This contrasts with a profound inhibition of the primary immune response seen with the Ii-deficient mouse (46), or the severely defective immune response of patients with bare lymphocyte syndrome (47). Interestingly, B cells from Ii-deficient mice show a developmental arrest and do not generate a normal IgM response to a T cell-independent antigen (48). This contrasts with results found in this study and from those observed with class II-deficient mice (39), again suggesting that phenotypic differences exist between cathepsin S-deficient and Ii-deficient animals.

A possible clue to the basis of the partial effects seen with inhibition of cathepsin $\mathrm{S}$ is our observation that overall surface MHC class II levels, as judged by flow cytometry, and levels of surface class II-peptide complexes, as determined by surface biotinylation experiments, do not change after administration of LHVS for 2 wk (data not shown). This suggests that the kinetics of class II-peptide binding may be more profoundly affected than the final ability of class II molecules to associate with antigenic peptides. This is not totally unexpected because 
maturation of MHC class II molecules and generation of class II-peptide complexes require an intricate interplay of several proteolytic events. Class II-Ii complexes must be rendered competent for binding peptide by efficient degradation of intact Ii, antigenic peptides must be generated at sufficiently high concentrations to promote class II-peptide association, and degradation of antigenic peptides must not occur before the peptide can find refuge in the class II binding pocket. Thus, kinetic alteration of one or more of these determinants may result in a profound alteration in the immune response with a much less pronounced alteration of steady-state class II and class II-peptide levels. In support of this hypothesis, experimental evidence suggests that HLA-DM can interact, albeit less efficiently, with larger class II-Ii species compared with class II-CLIP (49). Furthermore, different antigenic epitopes may have different intrinsic affinities for class II molecules and may be able to differentially displace Ii fragments. Taken together, these data suggest that inhibition of cathepsin S may act to selectively modulate, rather than broadly suppress, immunity.

To further characterize the role of cathepsin S in immunity, we used a model of Th-2-driven allergic inflammatory responses in the lung to test the functional effects of selective cysteine protease inhibition on a hypersensitivity reaction. A priori, modulation of the immune response by inhibition of cathepsin $\mathrm{S}$ using this model is appealing because of the known dependence of Th-2 T cell subset maturation on antigen presentation. Previous studies in splenocytes from transgenic T cell receptor mice, which respond to $\mathrm{OVA}_{323-339}$ bound to class II molecules, show that $\mathrm{Th}-2 \mathrm{CD} 4^{+} \mathrm{T}$ cell subset maturation is dependent upon antigen dose (50), the affinity of peptide for the class II molecule, and hence the conformation of the class II-peptide complex (51), and the APC as well (52). Selective inhibition of cathepsin S had a profound effect on the development of pulmonary hypersensitivity in this model. This was evidenced by an attenuation of serum $\operatorname{IgE}$ titers as well as a blockade of inflammatory cell infiltration into the lung. Also, the abrogation of the IgE response may have an additive effect on the inability of the inhibited mice to effectively present antigenic peptide by preventing antigen capture and uptake through the CD23 and FceRIII IgE cell surface receptors (53).

Pulmonary hypersensitivity and inflammation with eosinophilic infiltration is a prominent feature of allergic airway diseases, including asthma (54). Activated eosinophils release several inflammatory mediators including cationic proteins, lipids, and oxygen radicals which participate in airway inflammation and injury (55). Therapeutic strategies for modulating the immune response in asthma, and other autoimmune disorders, have centered on altering generation of the effector molecules which mediate the inflammatory reactions, e.g., corticosteroids, cyclosporin, and leukotriene inhibitors (56). Recently, attempts to inhibit more proximal events by blocking $\mathrm{T}$ cell costimulation have also been reported $(42,57)$. Our experiments demonstrate that selective inhibition of cysteine proteases is an additional potential strategy for modulating the immune response in class II-restricted disease processes.

An important caveat to the in vivo studies is that we cannot be sure that only cathepsin $\mathrm{S}$ is inhibited. The second order rate constant for inhibition of cathepsin $S$ is 6,000 times greater than that for cathepsin B, but only 60 and 30 times greater than that for cathepsins $\mathrm{L}$ and $\mathrm{K}$, respectively (29). Thus, in vivo, it is difficult to control the delivery of LHVS tightly enough to distinguish between these three cysteine endoproteases (cathepsins S, L, and K). Cathepsin K is not found in APCs, but cathepsin L is found in some murine B cells (Fig. 1) and dendritic cells (data not shown). Can cathepsin L compensate for the absence of cathepsin $\mathrm{S}$ in degrading Ii from $\alpha \beta$ Ii complexes, rendering class II molecules competent for binding peptide? Both cathepsins $\mathrm{S}$ and $\mathrm{L}$ are potent endoproteases with overlapping, but not identical substrate profiles. Evidence in favor of a role for cathepsin L in Ii processing is found in mouse fibroblast $3 T 3$ cells, in which inhibition of cathepsin L generates accumulation of Ii fragments similar to that seen with inhibition of cathepsin S in murine splenocytes and human B cells (24). Evidence against a role for cathepsin $\mathrm{L}$ in Ii processing is provided by in vitro studies in our laboratory using purified human cysteine proteases and $\alpha \beta I$ i complexes, demonstrating that the concentration of cathepsin L required for generation of $\alpha \beta$ CLIP from $\alpha \beta I$ i complexes is $>10$ times that of cathepsin $\mathrm{S}$ (data not shown). Furthermore, data presented in this manuscript with careful titration of LHVS in vitro with A20 cells (Figs. 1 and 2) demonstrate that cathepsin L cannot totally compensate for the absence of cathepsin S. This may be a consequence of kinetic differences in generation of $\alpha \beta$-CLIP, or may reflect differences in transport and compartmentalization of these two enzymes in A20 cells. Precise delineation of the exact roles of these two proteases in vivo may require genetic manipulation.

Recent experimental evidence has illustrated the importance of haplotype to class II-Ii processing. Inhibition of cysteine proteases with leupeptin in splenocytes expressing class II molecules of the I-A ${ }^{b}$ and I- $\mathrm{A}^{\mathrm{d}}$ haplotypes causes accumulation of Ii breakdown intermediate lip10, with a concomitant attenuation of SDS-stable class II-peptide complex formation. Alternatively, inhibition of cysteine proteases in splenocytes expressing $\mathrm{I}-\mathrm{A}^{\mathrm{k}}$ and $\mathrm{I}-\mathrm{A}^{\mathrm{u}}$ class II molecules does not result in accumulation of Ii fragments or a decrease in SDS-stable class II-peptide complex formation (28). This suggests that $\mathrm{I}_{-} \mathrm{A}^{\mathrm{b}}$ and I-A ${ }^{\mathrm{d}}$ class II molecules are more dependent upon cysteine proteases for efficient Ii proteolysis and subsequent peptide loading than are $\mathrm{I}-\mathrm{A}^{\mathrm{k}}$ and $\mathrm{I}-\mathrm{A}^{\mathrm{u}}$. Even between the $\mathrm{I}-\mathrm{A}^{\mathrm{b}}$ and I-A ${ }^{d}$ haplotypes, inhibition of cysteine proteases with leupeptin has differing effects on class II trafficking through the endocytic pathway (58). The C57BL/6 mice and A20 cells used in this manuscript express class II molecules of the $\mathrm{H}-2^{\mathrm{b}}$ and $\mathrm{H}-2^{\mathrm{d}}$ haplotypes, respectively. It is possible that, in mice of other haplotypes, selective inhibition of cysteine proteases may lead to less profound, or different, alterations in immunity.

Although we have focused on cathepsin S, the realization that several class II-restricted diseases appear to be driven by only a few dominant antigenic epitopes, and by implication perhaps only a single protease, raises the possibility that selective inhibition of additional cysteine and lysosomal proteases may be immunomodulatory. For example, in vivo administration of an inhibitor of cathepsin B attenuates the antibody response to hepatitis B antigen in Balb/c mice, thought to occur by interruption of antigen processing (59). Also, as stated above, cathepsin L has been linked to antigenic peptide degradation in murine fibroblast 3T3 cells (24). Our experiments directly demonstrate a correlation between altered Ii processing, antigen presentation, and immunity. Thus, selective inhibition of cysteine proteases, cathepsin S in particular, may have important therapeutic potential in modulating class II-restricted immune processes. 


\section{Acknowledgments}

We wish to thank Dr. Eveline Schneeberger (Massachusetts General Hospital, Boston, MA) for her assistance with the mouse lung sections, and Dr. Giu-Quin Jia (Millennium Pharmaceuticals, Cambridge, MA) for generously supplying the eotaxin. We would also like to express our gratitude to Dr. Xiao-Wei Kang, Krista Barnes-Condon, Aiping Jiao, and Ross M. Fujita for their technical assistance.

This work was supported by National Institutes of Health grants T32-HL-07633 (R.J. Riese), GM47726 (R.N. Mitchell), HL-48261 (H.A. Chapman), 5-RO-AI34893 (H.L. Ploegh), and 2-P30-CA14051-24 (H.L. Ploegh). J.A. Villadangos was supported by fellowships from the Ministerio de Educacion y Ciencia (Spain) and the Lady Tata Foundation (UK).

\section{References}

1. Cresswell, P. 1994. Antigen presentation. Getting peptides onto MHC class II molecules. Curr. Biol. 4:541-543.

2. Germain, R.N. 1994. MHC-dependent antigen processing and peptide presentation: providing ligands for T lymphocyte activation. Cell. 76:287-299.

3. Wolf, P.R., and H.L. Ploegh. 1995. How MHC class II molecules acquire peptide cargo: biosynthesis and trafficking through the endocytic pathway. Annu. Rev. Cell Dev. Biol. 11:267-306.

4. Roche, P.A., M.S. Marks, and P. Cresswell. 1991. Formation of a ninesubunit complex by HLA class II glycoproteins and the invariant chain. Nature. 354:392-394.

5. Lamb, C., and P. Cresswell. 1992. Assembly and transport properties of invariant chain trimers and HLA-DR-invariant chain complexes. J. Immunol. 148:3478-3482.

6. Bijlmakers, M.-J.E., P. Benaroch, and H.L. Ploegh. 1994. Mapping functional regions in the lumenal domain of the class II-associated invariant chain. J. Exp. Med. 180:623-629.

7. Ghosh, P., M. Amaya, E. Mellins, and D.C. Wiley. 1995. The structure of an intermediate in class II maturation: CLIP bound to HLA-DR3. Nature. 378: $457-462$

8. Rudensky, A.Y., P. Preston-Hurlburt, S.C. Hong, A. Barlow, and C.A. Janeway, Jr. 1991. Sequence analysis of peptides bound to MHC class II molecules. Nature. 353:622-627.

9. Riberdy, J.M., J.R. Newcomb, M.J. Surman, J.A. Barbosa, and P. Cresswell. 1992. HLA-DR molecules from an antigen-processing mutant cell line are associated with invariant chain peptides. Nature. 360:474-476.

10. Chicz, R.M., R.G. Urban, W.S. Lane, J.C. Gorga, L.J. Stern, D.A.A. Vignali, and J.L. Strominger. 1992. Predominant naturally processed peptides bound to HLA-DR1 are derived from MHC-related molecules and are heterogeneous in size. Nature. 358:764-768.

11. Amigorena, S., J.R. Drake, P. Webster, and I. Melman. 1994. Transient accumulation of new class II MHC molecules in a novel endocytic compartment in B lymphocytes. Nature. 349:113-120.

12. Tulp, A., D. Verwoerd, B. Dobberstein, H.L. Ploegh, and J. Peters. 1994. Isolation and characterization of the intracellular MHC class II compartment. Nature. 349:120-126.

13. West, M.A., J.M. Lucocq, and C. Watts. 1994. Antigen processing and class II MHC peptide-loading compartments in human B-lymphoblastoid cells. Nature. 369:147-151.

14. Denzin, L.K., and P. Cresswell. 1995. HLA-DM induces CLIP dissociation from MHC class II alpha beta dimers. Cell. 82:155-165.

15. Sherman, M.A., D.A. Weber, and P.E. Jensen. 1995. DM enhances peptide binding to class II MHC by release of invariant chain-derived peptide. Immunity. 3:197-205.

16. Sloan, V.S., P. Cameron, G. Porter, M. Gammon, M. Amaya, E. Mellins, and D.M. Zaller. 1995. Mediation by HLA-DM of dissociation of peptides from HLA-DR. Nature. 375:802-806.

17. Roche, P.A., and P. Cresswell. 1990. Invariant chain association with HLA-DR molecules inhibits immunogenic peptide binding. Nature. 345:615-618.

18. Blum, J.S., and P. Cresswell. 1988. Role for intracellular proteases in the processing and transport of class II HLA antigens. Proc. Natl. Acad. Sci. USA. 85:3975-3979.

19. Nguyen, Q., V. Knapp, and R.E. Humphreys. 1988. Inhibition by leupeptin and antipain of the intracellular proteolysis of Ii. Hum. Immunol. 24: $153-163$.

20. Newcomb, J.R., and P. Cresswell. 1993. Structural analysis of proteolytic products of MHC class II-invariant chain complexes generated in vivo. J. Immunol. 151:4153-4163.

21. Neefjes, J.J., and H.L. Ploegh. 1992. Inhibition of endosomal proteolytic activity by leupeptin blocks surface expression of MHC class II molecules and their conversion to SDS resistant $\alpha \beta$ heterodimers in endosomes. EMBO (Eur. Mol. Biol. Organ.) J. 11:411-416.
22. Reyes, V.E., S. Lu, and R.E. Humphreys. 1991. Cathepsin B cleavage of Ii from MHC $\alpha$ - and $\beta$-chains. J. Immunol. 146:3877-3880.

23. Bevec, T., V. Stoka, G. Pungercic, I. Dolenc, and V. Turk. 1996. Major histocompatibility complex class II-associated p41 invariant chain fragment is a strong inhibitor of lysosomal cathepsin L. J. Exp. Med. 183:1331-1338.

24. Fineschi, B., K. Sakaguchi, E. Appella, and J. Miller. 1996. The proteolytic environment involved in MHC class II-restricted antigen presentation can be modified by the p41 form of invariant chain. J. Immunol. 157:3211-3215.

25. Van Noort, J.M., and A.C.M. Van der Drift. 1989. The selectivity of cathepsin D suggests an involvement of the enzyme in the generation of T-cell epitopes. J. Biol. Chem. 264:14159-14164.

26. Rodriguez, G.M., and S. Diment. 1992. Role of cathepsin D in antigen presentation of ovalbumin. J. Immunol. 149:2894-2898.

27. Riese, R.J., P.R. Wolf, D. Bromme, L.R. Natkin, J.A. Villadangos, H.L. Ploegh, and H.A. Chapman. 1996. Essential role for cathepsin S in MHC class II-associated invariant chain processing and peptide loading. Immunity. 4:357-366.

28. Villadangos, J.A., R.J. Riese, C. Peters, H.A. Chapman, and H.L. Ploegh. 1997. Degradation of mouse Ii: roles of cathepsins S and D and the influence of allelic polymorphism. J. Exp. Med. 186:549-560.

29. Palmer, J.T., D. Rasnick, J.L. Klaus, and D. Bromme. 1995. Vinyl sulfones as mechanism-based cysteine protease inhibitors. J. Med. Chem. 38:31933196.

30. Buus, S., S. Colon, C. Smith, J.H. Freed, C. Miles, and H.M. Grey. 1986. Interaction between a "processed" ovalbumin peptide and Ia molecules. Proc. Natl. Acad. Sci. USA. 83:3968-3971.

31. Shaw, A.C., R.N. Mitchell, Y.K. Weaver, J. Campos-Torres, A.K. Abbas, and P. Leder. 1990. Mutations of immunoglobulin transmembrane and cytoplasmic domains: effects on intracellular signaling and antigen presentation. Cell. 63:381-392.

32. Metlay, J.P., M.D. Witmer-Pack, R. Agger, M.T. Crowley, D. Lawless, and R.M. Steinman. 1990. The distinct leukocyte integrins of mouse spleen dendritic cells as identified with new hamster monoclonal antibodies. J. Exp. Med. 17:1753-1771.

33. Shi, G.-P., A.C. Webb, K.E. Foster, J.H.M. Knoll, C.A. Lemere, J.S Munger, and H.A. Chapman. 1994. Human cathepsin S: chromosomal localization, gene structure, and tissue distribution. J. Biol. Chem. 269:11530-11536.

34. White, J., M. Blackman, J. Bill, J. Kappler, P. Marrack, and W. Born. 1989. Two better cell lines for making hybridomas expressing specific T cell receptors. J. Immunol. 143:1822-1825.

35. Griffith, J.I., N. Nabavi, Z. Ghogawala, C.G. Chase, M. Rodriguez, D.J. McKean, and L.H. Glimcher. 1988. Structural mutation affecting intracellular transport and cell surface expression of murine class II molecules. J. Exp. Med. 167:541-555.

36. Mason, R.W., D. Wilcox, P. Wikstrom, and E.N. Shaw. 1989. The identification of active forms of cysteine proteinases in Kirsten-virus-transformed mouse fibroblasts by use of specific radiolabeled inhibitor. Biochem J. 257:125-129.

37. Barnes, K.A., and R.N. Mitchell. 1995. Detection of functional class IIassociated antigen: role of a low density endosomal compartment in antigen processing. J. Exp. Med. 181:1715-1727.

38. Karasuyama, H., and F. Melcher. 1988. Establishment of mouse cell clones which constitutively secrete large quantities of interleukin $2,3,4$, or 5 using modified cDNA expression vectors. Eur. J. Immunol. 18:97-104.

39. Grusby, M.J., H. Auchincloss, Jr., R. Lee, R.S. Johnson, J.P. Spencer, M. Zijlstra, R. Jaenisch, V.E. Papaioannou, and L.H. Glimcher. 1993. Mice lacking major histocompatibility complex class I and class II molecules. Proc. Natl. Acad. Sci. USA. 90:3913-3917.

40. Kung, T.T., H. Jones, G.K. Adams III, S.P. Umland, W. Kreutner, R.W. Egan, R.W. Chapman, and A.S. Watnick. 1994. Characterization of a murine model of allergic pulmonary inflammation. Int. Arch. Allergy Immunol. 105:83-90.

41. Ohkawara, Y., X.-F. Lei, M.R. Stampfli, J.S. Marshall, Z. Xing, and M. Jordana. 1997. Cytokine and eosinophil responses in the lung, peripheral blood and bone marrow compartments in a murine model of allergen-induced airways inflammation. Am. J. Respir. Cell Mol. Biol. 16:510-520.

42. Krinzman, S.J., G.T. De Sanctis, M. Cernadas, D. Mark, Y. Wang, J. Listman, L. Kobzik, C. Donovan, K. Nassr, I. Katona, et al. 1996. Inhibition of $\mathrm{T}$ cell costimulation abrogates airway hyperresponsiveness in a murine model. J. Clin. Invest. 98:2693-2699.

43. Bozic, C.R., L.F. Kolakowski, Jr., N.P. Gerard, C. Garcia-Rodriguez, C. von Uexkull-Guldenband, M.J. Conklyn, R. Breslow, H.J. Showell, and C. Gerard. 1995. Expression and biologic characterization of the murine chemokine KC. J. Immunol. 154:6048-6057.

44. Frevert, C.W., S. Huang, H. Danaee, J.D. Paulauskis, and L. Kobzik. 1995. Functional characterization of the rat chemokine KC and its importance in neutrophil recruitment in a rat model of pulmonary inflammation. J. Immunol. 154:335-344.

45. Diment, S. 1990. Different roles for thiol and aspartyl proteases in antigen presentation of ovalbumin. J. Immunol. 145:417-422.

46. Viville, S., J. Neefjes, V. Lotteau, A. Dierich, M. Lemeur, H. Ploegh, C. Benoist, and D. Mathis. 1993. Mice lacking the MHC class II-associated invariant chain. Cell. 72:635-648.

47. Griscelli, C., B. Lisowska-Grospierre, and B. Mach. 1989. Combined immunodeficiency with defective expression in MHC class II genes. Immunodefic. 
Rev. 1:135-153.

48. Shachar, I., and R.A. Flavell. 1996. Requirement for invariant chain in B cell maturation and function. Science. 274:106-108.

49. Denzin, L.K., C. Hammond, and P. Cresswell. 1996. HLA-DM interactions with intermediates in HLA-DR maturation and a role for HLA-DM in stabilizing empty HLA-DR molecules. J. Exp. Med. 184:2153-2165.

50. Hosken, N.A., K. Shibuya, A.W. Heath, K.M. Murphy, and A. O'Garra. 1995. The effect of antigen dose on $\mathrm{CD}^{+}{ }^{+} \mathrm{T}$ helper cell phenotype development in a T cell receptor $\alpha \beta$ transgenic model. J. Exp. Med. 182:1579-1584.

51. Pfeiffer, C., J. Stein, S. Southwood, H. Ketelaar, A. Sette, and K. Bottomly. 1995. Altered peptide ligands can control CD4 T lymphocyte differentiation in vivo. J. Exp. Med. 181:1569-1574.

52. Gajewski, T.F., M. Pinas, T. Wong, and F.W. Fitch. 1991. Murine Th1 and Th2 clones proliferate optimally in response to distinct antigen-presenting cell populations. J. Immunol. 146:1750-1758.

53. Mudde, G.C., I.G. Reischl, N. Corvaia, S. Hren, and E.-M. Poellabauer. 1996. Antigen presentation in allergic sensitization. Immunol. Cell Biol. 74:167-173.
54. Beasley, R., W.R. Roche, J.A. Roberts, and S.T. Holgate. 1989. Cellular events in the bronchi in mild asthma and after bronchial provocation. Am. Rev. Respir. Dis. 139:806-817.

55. Venge, P., and L. Hakansson. 1991. Current understanding of the role of the eosinophil granulocyte in asthma. Clin. Exp. Allergy. 21(Suppl. 3):31-37.

56. Woolcock, A.J. 1994. Asthma. In Textbook of Respiratory Medicine. J.F. Murray and J.A. Nadel, editors. W.B. Saunders Co., Philadelphia. 12881330.

57. Linsley, P.S., P.M. Wallace, J. Johnson, M.G. Gibson, J.L. Greene, J.A Ledbetter, C. Singh, and M.A. Tepper. 1992. Immunosuppression in vivo by a soluble form of the CTLA-4 T cell activation molecule. Science. 257:789-792.

58. Brachet, V., G. Raposo, S. Amigorena, and I. Mellman. 1997. Ii controls the transport of major histocompatibility class II molecules to and from lysosomes. J. Cell Biol. 137:51-65.

59. Matsunaga, Y., T. Saibara, H. Kido, and N. Katunuma. 1993. Participation of cathepsin B in processing of antigen to MHC class II. FEBS Lett. 324: 325-330. 